Andrzej Pawet Wejland ${ }^{*}$

\title{
ANTROPOLOG I POJĘCIE ŚWIADECTWA. O NIEKTÓRYCH PULAPKACH W BADANIU TERENOWYM
}

\section{POJĘCIE ŚWIADECTWA - ROZPOZNANIE WSTĘPNE}

Jak Paul Ricoeur przy pewnej - niedotyczącej świadectwa - konceptualnej wątpliwości, chciałbym, już o świadectwie właśnie, stwierdzić, że nie jest to ,pseudopojęcie grożące autorowi poszukującemu nowości wpadnięciem w pułapkę fałszywego tematu" (R i c o e u r 2004: 5). Próżno, by dziś w antropologii kulturowej i szeroko pojętej humanistyce rozglądać się za „poważnym” autorem, który nowości upatrywałby akurat w użyciu tego pojęcia. Nie służy ono zresztą od dawna terminologicznym odkryciom, ponieważ w dyskursie badawczym zdążyło chyba zaimponować wszystkimi możliwymi znaczeniowymi odcieniami. Do odkrycia czegoś istotnie nowego nie dochodzi nawet wtedy, gdy pojęcie świadectwa, w słusznym odczuciu semantycznie zamglone, ktoś poddaje uściśleniu, stosując wobec niego wyrafinowane - i swoją drogą metodologicznie ciekawe - definicyjne regulacje lub eksplikacje. Owszem, autor może mieć wrażenie, że w pewien szczególny sposób używając pojęcia świadectwa, wpada na trop czegoś nowego dla siebie samego i dla innych, zwłaszcza dla swojej lokalnej wspólnoty badawczej. Te „małe odkrycia” okazują się jednak zwykle, gdy rozejrzy się po szerokim świecie, albo ignoranckimi odkryciami Ameryki, albo (co dotyczy tylko erudytów) nieświadomymi - jak je określał Robert K. M e r t o n (2011; patrz M e r t o n 1982: 52-56) - plagiatami, czyli zapożyczeniami niewinnymi, bo zawinionymi wyłącznie przez kryptomnezję. Gdyby pojęcie świadectwa w jakimś okresie zostało zapomniane, odkrywanie go i podrywanie do teoretycznego i badawczego lotu byłoby niewątpliwym osiągnięciem, ale „nowością? jedynie na tle takiego czasowego przesłonięcia. Czy jednak dyskurs w humanistyce ostatnich dziesięcioleci nie zdobył się na jego wydobycie z cienia?

Ponieważ zawsze miałem upodobanie do - i sporą łatwość - systematyzowania pojęć, zainteresowawszy się świadectwami religijnymi, a wśród nich tymi,

* Prof. dr hab., socjolog i antropolog kultury, metodolog, Zakład Teorii i Badania Kultury Współczesnej, Instytut Etnologii i Antropologii Kulturowej, Uniwersytet Łódzki, ul. Pomorska 149/153, 90-236 Łódź; apw@autograf.pl. 
które wypowiadają (i składają) katoliccy charyzmatycy, przystąpiłem natychmiast do uznawanych za domenę „teorii” pojęciowych porządków. Domena „teorii” to głównie, oparte na czytaniu innych autorów, układanie dla siebie, w ciszy gabinetu, słów i ich znaczeń w mniej lub bardziej rozbudowane pojęciowe struktury. Praca więc pożyteczna, chociaż - jak wszelkie rozważania „czysto pojęciowe” - nieznająca jeszcze smaku łagodnego spotkania lub gwałtownego zderzenia z „empirią": z własną, usiłującą przełamać szablony i przez to niepewną lub wręcz nieporadną praktyką badania $\mathrm{w}$ terenie, oraz $\mathrm{z}$ odsłanianym przez nią światem „żywych" świadectw. Układanie pojęć w eleganckie (i logicznie poprawne) klasyfikacje albo (mniej niż klasyfikacje rygorystyczne) typologie, a bardziej jeszcze w rozwinięte tematyczne sieci, hierarchie i pola, „nowością” bywa oczywiście o tyle, że - przez pełne oryginalności odniesienie do klasyków, do prac mniej klasycznych - wprowadza do dyskursu naukowego myślowy ferment, proponuje (wciąż chciałoby się w to wierzyć) niebanalne spojrzenie na „problem świadectw” albo tylko (czy aż) płodną w badawcze pomysły konceptualną, ,teoretyczną" metarefleksję.

W przekonaniu, że przynajmniej po części takie mogą okazać się moje własne pojęciowe systematyzacje, począłem najpierw odróżniać - mając za sobą sporo lektur - dwa sposoby użycia słowa „świadectwo”. Oba wspólnie uznawały, że świadectwo jest szczególną relacją, sprawozdaniem, raportem, także opowieścią lub opowiedzianą historią, mającą - co je pośród innych takich tekstów wyróżnia i czyni „świadectwami” - posmak „faktyczności” i „obiektywnej prawdziwości”, przez to więc walor dokumentu stwierdzającego, że „było tak a tak”; zakładały też zgodnie, że jest to mówiony lub pisany tekst przedstawiany innym, by i oni wiedzieli to, co o pewnych faktach i zdarzeniach wie ten, kto go im przedstawia. Była to, jak łatwo zauważyć, zgoda na traktowanie świadectwa jako tekstu określonego co do swojego związku z rzeczywistością, a przez to i formy nadającej się do opisu przede wszystkim owych faktów i zdarzeń. Była to także zgoda na ujmowanie świadectwa określonego na gruncie jego intencji komunikacyjnych, inaczej mówiąc, zgoda na to, by dopatrywać się w nim odrębnego gatunku czy też genre'u mowy, a choćby tylko formy słownej realizującej tak określoną postawę i wobec faktów lub zdarzeń, i wobec słuchacza lub czytelnika. Świadectwo można by na tej podstawie odróżniać od innych podobnych tekstów, np. - zawdzięczam tę dystynkcję Małgorzacie C z e r m iń s k i ej (2000: 9-52) - od tych, w których dominują postawy wyznania lub wyzwania.

$\mathrm{Na}$ czym wobec tego polegała różnica między każdym z tak bliskich sobie sposobów użycia słowa ,świadectwo”? Różnica polegała na zakresie i abstrakcyjności lub konkretności każdego z nich.

Pierwszy sposób to użycie słowa „świadectwo" tak, by dotyczyło ono wszelkich tekstów mających określone cechy gatunkowe (mówiąc, że to teksty słowne, i tak ograniczyłem ich zakres). Dla tego ogólnego użycia słowa „świadectwo" nie 
jest więc istotne, jak tekst zanurzony jest w kulturowym kontekście i czy jego wynikające z tej konkretyzacji - nastawienie wobec słuchacza lub czytelnika ma choćby wymiar wspólnotowy, tzn. odzwierciedla istnienie wspólnoty, ale i ustanawia bądź umacnia wspólnotę, dającą się przez to nazwać wspólnotą świadectwa. Wszystkie te, pomijane definicją, okoliczności mogą być oczywiście brane pod uwagę jako charakterystyki fragmentów rzeczywistości, do której pojęcie ogólne się odnosi. Mogą zatem ujawnić, że pojęcie świadectwa kryje w sobie wielką - dającą się przecież uporządkować - kulturową rozmaitość tekstów, tu jednak pomijaną za cenę wydzielenia tego, co w nich wspólne.

Drugi sposób użycia słowa ,świadectwo”, eksponujący konkretny kulturowy kontekst lub przynajmniej nie najogólniejszą klasę takich kontekstów, jest zazwyczaj z logicznego punktu widzenia obciążony eliptycznością: nie dopowiada tego akurat, że ze słowem ,świadectwo" wiążą się nie tylko treści ogólne, ale i szczegółowe. W gruncie rzeczy słowo „świadectwo” występuje tu jedynie jako wyrażenie skrótowe. Gdy ktoś wyjaśnia, że zajmuje się - przechowywaną w ich pamięci - historią Sybiraków, więźniów Gułagu lub ofiar Zagłady, słowo „świadectwo" (jeśli tylko nie zaznacza, że ma być inaczej) odnosi się do „świadectw Sybiraków" (R z e p k o w s k a 2009), „świadectw więźniów Gułagu” (S a r i u s z-S k ą p s k a 1995) lub „świadectw ofiar Zagłady” (En g elk ing 2001).

Często zresztą wyrażenia skrótowe i pełne występują obok siebie, bez przykrego zamieszania. Sposób użycia słowa „,́́wiadectwo” - czy ten ogólny, ,ponadkontekstowy", czy ten związany z kulturowym kontekstem - może być sprawą mniej lub bardziej dokładnie ważonych słów i ich znaczeń, trzymającego się przeto definicji lub od nich wolnego ,stylu” pisania autora; sprawą więc dla niego istotną albo mało znaczącą, jako wyczulonego na każde słowo lub unoszonego przez własną opowieść „stylisty”. Bywa jednak dla niektórych sprawą o wiele poważniejszą. Nie dość, że mogą oni - opowiadając się (za Herbertem Blumerem) po stronie strategii pojęciowego uwrażliwienia, odrzucać w ogóle, jako krępującą, paraliżującą myślenie, strategię pojęciowej precyzji, to mogą jeszcze samo ustalanie pojęć najogólniejszych, „ponad kulturowymi kontekstami”, uważać za interesujące co prawda dla ,abstrakcyjnych” metodologów, lecz dla praktyki antropologicznej nastawionej na badawczy szczegół i konkret przydatne co najwyżej jako gromadzenie wstępnych wskazówek, i tak wymagających konfrontacji z kulturowym kontekstem'.

Autorzy ci eksponują zwykle niepowtarzalność i osobliwość tego kontekstu, przez co również za niepowtarzalne i osobliwe - co do ich „gatunkowości” uważają związane z nim świadectwa. Po co mówić o świadectwie w ogóle, jeśli świadectwa religijne są od wielu innych tak odmienne, po co nawet rozważać

1 W sprawie wyróżnionych przez Herberta Blumera pojęć uwrażliwiających (nazywanych też u nas uczulającymi), bez wiązania ich wyłącznie z teorią ugruntowaną; patrz: P a t t o n 2002: 276-279, 456-457; H a m m e r s 1 e y 2006: 279-280; H o on a a r van den 2008: 812-814. 
ogólnie kwestię świadectw religijnych, skoro tak bardzo wyróżniają się wśród nich świadectwa charyzmatyczne, pośród nich zaś świadectwa fizycznego uzdrowienia itd. Kulturowy kontekst ściąga na ziemię, każe rezygnować z oderwanych „teoretycznych” rozważań w imię ścisłego związku z tym, co podsuwa on sam: w imię szczegółu i konkretu, w imię gęstości znaczeń, które go oplatają, ciekawszych - i ważniejszych - od ,pustych”, bo zbyt ogólnych i zbyt abstrakcyjnych ustaleń pojęciowych (w tym także wielostopniowych klasyfikacji lub typologii gatunków, podgatunków, drobniejszych odmian gatunkowych itp.). Kulturowy kontekst podsuwa przy okazji wygodną broń: pojęcie, które mieści się w kategorii ,świadectwa”, lecz odnosi się już tylko do niego, pojęcie zatem „ekskluzywne". Sądzę, iż taki właśnie charakter ma - odnoszone zakresem i treścią do szczegółowego kontekstu kulturowego - hiszpańskie słowo testimonio (częściej zresztą, chyba dla podkreślenia rangi zjawiska, używane w liczbie mnogiej). Badacze testimonios, które są oczywiście „świadectwami”, bardziej skupiają się na tym, co w testimonios kulturowo szczególnego, niż na tym, czy i o ile przystaje do nich jakaś wyjątkowo ogólna, pojemna definicja „świadectwa”. Tym, co od czasu opowieści Rigoberty Menchú wciąż trawi ich umysły, jest za to pytanie o udział antropologów w kreacji zawartej w tej opowieści „prawdy” albo - jak utrzymują niektórzy - zmyślenia, stającego wszakże w obronie uciśnionych i mordowanych Indian z Gwatemali (B e ver le y 2009; B ro ok s 2005; N an ce 2006).

Ktoś, kto troszczy się o stosowane przez siebie pojęcia, a choćby - jak Ricoeur - o to, by nie zrodziło ich (przypuszczalnie trochę niezdrowe) ,poszukiwanie nowości”, jest w jakiś sposób na grę pojęć w nauce wyczulony. „Inaczej wyczuleni” bywają ci, którzy zbierając opowieści, np. opowieści o mieście w paradygmacie historii mówionej, dopiero dla efektu ex post i bez wyjaśnień (dlatego zapewne na wyrost), używają wobec nich terminu ,świadectwo". Może też po prostu ulegają, jako narratywiści, dającemu się zauważyć w antropologicznej rodzinie pociągowi do tego słowa (Herbert, R odger 2007; Johnston, McIvor 2007). Nie każda opowieść - tu przydają się ogólne rozważania pojęciowe - jest świadectwem, nawet jeśli przedstawia fakty i zdarzenia, szczególnie z dawnych czasów dostępnych jedynie ,żywej” ludzkiej pamięci.

Oba sposoby użycia słowa „świadectwo" nie są względem siebie przeciwstawne i - co przed chwilą wyszło na jaw - w praktyce badawczej antropologa nie muszą być od siebie oddzielane. Pierwsze podsuwa w badaniu spojrzenie „od góry”, czyli od ogólnej „teorii” świadectwa, drugie - też przecież często „teoretyczne”, lecz na niższym poziomie lub o mniejszym zasięgu - domaga się zaczepienia pojęcia świadectwa na kulturowym szczególe i konkrecie, a zatem świadomości kontekstowego zawężenia i zagęszczenia, zakotwiczenia „od dołu”. Moje własne doświadczenie pokazuje, że dobrze jest poruszać się pomiędzy nimi: sposób pierwszy, zwłaszcza wsparty ogólnymi definicjami lub eksplikacjami, dyscyplinuje myśli $\mathrm{w}$ gabinecie, $\mathrm{w}$ badawczym terenie natomiast pozwala zaglądać za horyzont; sposób drugi - przecież nieunikający pojęciowych precyza- 
cji, choć niewzbijający się ku ogólnej „teorii” świadectwa - proponuje troskliwą krzątaninę na ograniczonym badawczym polu i radość z dotykania nie abstrakcji, lecz „żywych” świadectw. Przyjęcie każdego z nich po swojemu upewnia, że ani dla rozważań teoretycznych, ani dla rozglądania się w terenie za świadectwami jakiegoś odrębnego rodzaju, np. za charyzmatycznymi świadectwami fizycznego uzdrowienia i nawrócenia, nie tworzą one „pułapki fałszywego tematu”. Temat jest „prawdziwy” od dawna, a pułapki, jeśli gdzieś są zastawiane, nie wynikają z tego, że go ktoś „wydumał”, że jest jedynie - na mocy terminologicznego projektu i pojęciowego eksperymentu - myślową zjawą, tworem być może nawet rozkosznym dla lubiących układanki pojęciowe, lecz narażającym na zarzut zwodniczej reifikacji, czyli mówienia o tym, czego w realnym świecie kultury po prostu nie ma. Temat nie jest „fałszywy” i w tym znaczeniu, że - jako „nierealny” bądź wśród „realnych” mało ważny - miałby zakrywać lub wręcz unicestwiać dla dyskursu naukowego to, co w rzeczywistym świecie jest naprawdę ważne. Przekonywali się jakże często inni badacze, przekonywałem się nie raz, nie dwa, i ja, ile groźnych, niepokojących, dramatycznych zdarzeń, ile trudnych życiowych doświadczeń - przełomów rozrywających życie na pół, ale też historii kończących się (jak przy cudownych uzdrowieniach) całkiem szczęśliwie - znajduje odbicie w świadectwach. I oni, i ja uświadamialiśmy sobie, jak ważne są to zdarzenia dla pojedynczych ludzi i dla całych wspólnot. Jak istotne jest również dla nich, dla ich autobiograficznego spotkania $\mathrm{w}$ świadectwach $\mathrm{z}$ własnym życiem oraz dla opisania w nich przeżyć i pamięci wspólnoty, samo przedstawianie świadectw, czyli akt świadczenia, niekiedy - przy szczególnych zobowiązaniach i moralnych przynagleniach (jak właśnie w świadectwach uzdrowienia lub świadectwach tych, co przeżyli zesłanie na Syberię, pobyt w Gułagu lub hitlerowski obóz zagłady, by przywołać przypadki tragicznie wyraźne) - akt przedkładany nad samą opowiadaną historię albo równie ważny jak ona. Akt w istocie, zwłaszcza gdy wielokrotnie powtarzany, traktowany jako jej naturalny ciąg dalszy, jako narracyjna, niekończąca się próba zrozumienia zdarzeń i wysiłek, by wiedzę i prawdę o nich przekazać innym „ku pamięci”.

Niektórzy badacze, po ludzku przejęci, jako antropologowie bez mała zawodowo wyczuleni na takie zdarzenia i opowieści, gotowi byli przyjąć niełatwą rolę zaangażowanego „świadka świadków” - świadka zastępczego, szczególnie gdy głos świadków był zbyt słaby, gdy odbierała go im trauma lub gdy w dominującym kulturowo dyskursie w ogóle „głosu” byli pozbawieni: Elizabeth Burgos w sprawie Rigoberty Menchú, Aleksandra Rzepkowska w sprawie Sybiraków², Marcin Andrzej K a far (2004) w sprawie osób samotnych i chorych w jednym z łódzkich domów opieki, całe zastępy badaczy świadectw Holocaustu, także ci, którzy jak ja wkraczali z badawczym zamysłem do ukrytych i zamkniętych, a często zwyczajnie „niewidocznych” i ,niesłyszalnych” w swoich społecznych

2 Zapis nazwy Sybiracy za: R z e p k o w s k a 2009. 
niszach, wspólnot charyzmatycznych, pentekostalnych, albo innych wspólnot religijnych itp. Niektórzy z nich przyznawali się do spowodowanych takim zaangażowaniem wstrząsów egzystencjalnych i epifanii, do odmiany własnego życia naukowego, ja także do wzruszeń, współprzeżywania, a nawet do obnażających emocjonalną empatię łez - nieprzyzwoitych w świetle starych, ale wciąż pokutujących ideałów „,człowieka nauki” (nie wstydzę się tych łez, mówiłem wtedy do siebie, przeciwnie, do twarzy mi z nimi; to samo mówiłem do moich przyjaciół antropologów, podobnie jak ja myślących i równie jak ja otwartych na ,antropologiczne świadczenie").

Uporanie się z posądzeniem, że temat, jaki tu podejmuję, jest tematem „fałszywym”, pułapką zastawioną przez - może już nikt teraz tego nie powie - „pseudopojęcie” świadectwa, nie zwalnia od metodologicznej czujności. Uniknięcie tej pułapki nie oznacza, iż temat świadectw - gdy wkroczyć na wyznaczone nim pole - nie zastawia na badacza sideł i nie tworzy groźnych potrzasków. Na pociechę można od razu dodać, że to zasadzki spotykane również na innych polach eksplorowanych przez antropologów, aczkolwiek część z nich, a niektóre zwłaszcza, właściwe są jedynie badaniom zorientowanym narratywistycznie. Metodologiczne trudności lub kłopoty są poważne dla „poważnych” badaczy, czyli wymagających od nich przynajmniej chwili zastanowienia, a jeszcze lepiej zatrzymania się w badawczym rozpędzie po to, by zdążyć je wypatrzyć i nie wpaść w nie, lub znaleźć przed nimi usprawiedliwiającą osłonę na wypadek, gdy się to jednak przydarzy.

Jakie są to pułapki? Wskażę niektóre z nich, sięgając do własnych doświadczeń z badania charyzmatycznych świadectw uzdrowienia (por. We j 1 a n d 2004).

\section{ŚWIADECTWO JAKO OPOWIEŚĆ I PULAPKA NARRATYWISTYCZNEGO ZAUROCZENIA}

Najpierw więc o pułapce zauroczenia - zachłyśnięcia się podejściem narratywistycznym i zawierzenia mu bez reszty, ale właśnie na poziomie nie dość jeszcze dojrzałym, bez dostrzeżenia jego złożoności lub też tego, że jest wewnętrznie niejednolite i proponuje więcej, niż się na początku widzi, możliwości analitycznych i interpretacyjnych. Samego mnie nie zaskoczyło, że dałem się od razu porwać i uwieść narratologii zrodzonej w łonie pragmatyki lingwistycznej, po części strukturalistycznej, i teorii literatury. Dla kogoś takiego jak ja, to wymarzone miejsce do ćwiczeń intelektualnych: wszystko się tutaj usiłuje ogólnie określić, poddać uściśleniom pojęciowym, wyróżnić części, ich funkcje itd. Pewnie dzięki temu ujął mnie już dawno temu Teun A. van Dijk ze swoją systematyką funkcji, jakie w opowieściach (u niego akurat w codziennych opowieściach o mniejszościach etnicznych) pełnią ich rozmaite fragmenty (Dijk van 1989; Wejland 
1991: 119-127)3. Szczególną moją uwagę zwróciła pośród nich (i wciąż zwraca) eksplikacja - fragment opowieści, nie zawsze jej coda, pełniący funkcje objaśniającego komentarza, $w$ istocie więc retrospektywnie interpretujący opowiadane zdarzenia - w świadectwach charyzmatycznych interpretujący je w horyzoncie religijnym, tłumaczący choćby działaniem Boga cudowne uzdrowienie z nieuleczalnej choroby, relacjonowane we wcześniejszych fragmentach. Teun A. van Dijk w sporej części opierał się w swoim ujęciu na pracach Williama Labova, także tej fundamentalnej, której współautorem był Joshua Waletzky (wielu badających w ten sposób morfologię opowieści lub też opowiadania odwołuje się, co nie zaskakuje, do Władimira J. Proppa, Algirdasa J. Greimasa i ich licznych kontynuatorów). Ogólnie biorąc, jest to ujęcie o ogromnej wartości analitycznej i interpretacyjnej - nie ja jeden jako badacz świadectw charyzmatycznych po nie sięgnąłem (z Outi Pohjanheimo, zainteresowaną w tym samym czasie świadectwami składanymi podczas spotkań religijnego ruchu Nokia's Revival, wymieniliśmy - w ożywionej korespondencji - niejedną uwagę krytyczną, choć to ujęcie wspierającą; patrz P o h j a n h e i m o 2002; We j l a n d 2004: 45, 47).

Łatwo jednak pochłoniętemu nim badaczowi nie zauważyć, że świadectwo - charyzmatyczne, ale i każde inne - to opowieść, tyle że opowieść szczególna, co więcej, że rozsądne próby ustalenia jego cech gatunkowych muszą wyjść poza obręb tak formalnych rozważań i zwrócić się ku dyskursowi świadectw jako ich „środowisku życiowemu” (takie przyjmuję thumaczenie terminu Sitz im Leben, pochodzącego z biblistyki, poznanego przy okazji rozległych - jak widać - studiów nad świadectwami religijnymi). Świadectwo - jeśli ma być właśnie świadectwem, a nie przypadkową opowieścią - nie żyje i nie może żyć poza takim dyskursem. We wspólnocie charyzmatycznej dyskurs w znacznej części jest dzieleniem się świadectwami. Do mających swoje „środowisko życia” bez trudu zaliczymy również świadectwa sybiraków i więźniów Gułagu, ludzi, którzy przeżyli Holocaust, relacje wygnańców, uciskanych, zepchniętych na margines społecznego życia, ciężko lub przewlekle chorujących itp. Dyskurs świadectw ma różne napędzające mechanizmy, w wypadku świadectw religijnych, a charyzmatycznych w szczególności, wyraźny jest też - jakby go nazwał R i c o e u r (1993; patrz P a w ł o w s k i 1998) - impuls narracyjny. Sami opowiadający mówią, że do składania świadectw czują się wewnętrznie przynagleni, częściej jeszcze stwierdzają, że swoimi świadectwami muszą się dzielić. „Bo świadkiem jest ten - podpowiada o. Jan Andrzej Kłoczowski - kto doświadcza i dzieli się tym, czego doświadczył" (Boskie oko... 2003: 106). Świadectwo - jako opowieść - trudno zatem oderwać od świadka i jego doświadczenia, a także od sytuacji świadczenia. Głębszy sens sekwencji „od doświadczenia do świadczenia” odkrywa ks. Józef Tischner, gdy wyjaśnia: „Polskie słowo d o ś w i a d c z e n i e składa się z dwóch elementów:

3 Uwzględniam tutaj, a także w bibliografii, rosyjski przekład pracy van Dijka, z którego korzystałem przed laty; oto dane oryginału: D i j k 1984: 79-104. 
do i świadczenie. Pierwszy wskazuje na dążenie, drugi na świadectwo. Wzięte razem znaczą: dochodzenie do świadectwa" (T is chner 2006: 19, wyróżnienie w oryginale). Sekwencja ta, z pośredniczącym ogniwem opowieści, zdaniem niektórych badaczy narracji - jako sekwencja dzielenia się świadectwami - urzeczywistnia relację daru w spotkaniu, które opisać już możemy jako wydarzenie wspólnoty.

W myśleniu o świadectwach jako opowieściach (lub też opowiadaniach) i stosowaniu wobec nich narzędzi narratologicznych nie ma - do czego chcę przekonać - niczego niestosownego, przeciwnie, to bardzo płodne ujęcie. Gdyby jednak, szukając ich ,gatunkowej natury”, poprzestać na takim myśleniu i takich narzędziach, i przynajmniej w tle nie zakładać lub nie dopuszczać możliwości ani potrzeby rozważenia ich miejsca w dyskursie - chętnie dodałbym, że chodzi o dyskurs wspólnotowy - stałoby się ono, zwłaszcza dla antropologa, ograniczającym ruchy potrzaskiem. Tego, że zasadzek takich można uniknąć, dowodzi przeczytana przeze mnie (z żalem to stwierdzam) z pewnym opóźnieniem - praca Małgorzaty Danuty N o w a k (2005: 5, wyróżnienie w oryginale), będąca „próbą lingwistycznego opisu świadectwa, formy wypowiedzi, pisanej i mówionej, znamiennej [...] dla współczesnego życia religijnego". Badając świadectwa religijne jako wypowiedzi, przyjmuje ona - czym ujawnia swoją szerszą perspektywę badawczą - iż są to ,zachowania językowe związane ze współczesnym dyskursem religijnym", będącym, zgodnie z cytowanym przez nią Piotrem Chruszczewskim, formą „określonej społecznej praktyki” (N ow a k 2005: 5 wraz z przypisem 1).

\section{„PRAWDA NARRACYJNA" ŚWIADECTWA I PULAPKA PORZUCENIA JEGO „PRAWDY HISTORYCZNEJ”}

Drugie niebezpieczeństwo wiąże się z przesadną, nadmiernie gorliwą postawą obronną, jaką antropologowie - oni zwłaszcza, choć także inni humaniści dzisiaj - zajmować często muszą wobec zakusów historyków. Może to ślady traktowania wciąż antropologii (etnologii, etnografii) jako nauki pomocniczej historii, a może po prostu paradygmatyczne zamknięcie, fakt jednak dla antropologów trudny do pojęcia i bolesny: niezrozumienie przez wiernych „staremu”, pozytywistycznemu paradygmatowi historyków - czyli, na szczęście, nie wszystkich historyków że w opowieściach zbieranych od „zwykłych ludzi”, opartych zatem na ich pamięci lub sięgających do zasobów generacyjnej postpamięci (choćby więc jako „historii mówionej”), antropologowie nie szukają „obiektywnych” faktów i zdarzeń, lecz ich „subiektywnych” znaczeń - ich indywidualnych lub, co ważniejsze, wspólnotowych interpretacji. Kiedy uczony historyk - przy publicznej okazji domaga się od nas sprawdzania w oficjalnych, pisanych dokumentach faktów, które jego zdaniem (a jest w tej materii naprawdę wielkiej klasy specjalistą), błędnie zostały przedstawione np. w świadectwach Sybiraków - protestujemy. W re- 
aliach współczesnej nauki to gest emancypujący, sprzeciw słabszej „mniejszości” względem intelektualnego ucisku silniejszej „większości”, ale też objaw niekończącej się walki paradygmatów. Antropologowie nie porzucają całkiem "starego" i nie oddają wyłącznej czci „nowemu”, skoro jednak za (naprawdę i w ścisłym sensie) antropologiczne uważają podejście „nowe” - niechże im wolno będzie badać sprawy po swojemu. Gdybym sam tego niezrozumienia nie doświadczył i tych zarzutów „nienaukowości” nie usłyszał (a jeszcze bardziej moi uczniowie), nie byłbym z pewnością tak radykalnym antropologicznym apologetą.

Jako metodolog powinienem wszakże wyjaśnić, na czym ta odmienność ujęć polega. Pomóc w tym może dobrze znane odróżnienie „prawdy historycznej” od „prawdy narracyjnej” (L i n c oln 2000: 133; R i m m o n-K e n a n 2006; Polkinghorne 2007; E11is, Bochner 1999; Kreiswirth 2000; Ros ner 2003: 112-117). Ta pierwsza to „prawda faktów i zdarzeń”, wobec której opowieść jest wierna, czyli zachowuje „prawdziwość”, pod warunkiem że fakty i zdarzenia przedstawia takimi, jakimi były w rzeczywistości. Mówi się o niej, że to prawda „logiczna”, słusznie kojarząc wymóg zgodności z rzeczywistością z klasyczną - jak ją nazywają logicy i filozofowie - definicją prawdy. Mówi się również, iż to „prawda obiektywna”, mając w przybliżeniu to samo na myśli. W przeciwieństwie do niej „prawda narracyjna” jest „subiektywna”: jakkolwiek opowieść może być zgodna z rzeczywistością, to może też jej przedstawienia „subiektywnie" odkształcać. Odkształcać zatem w wyniku osłabionej pamięci, przez ekspozycję doświadczania faktów i zdarzeń bardziej niż ich samych, przez nasycenie aurą emocjonalną, albo dzięki temu (tak właśnie powiedziałby z pewnością Ricoeur), że wszelkim faktom i zdarzeniom, zwłaszcza z własnego życia, nadajemy lub wręcz (jako urodzeni narratorzy) musimy w opowieści o nim nadawać wciąż na nowo, scalające jej interpretacje - one bowiem konstruują naszą ,tożsamość narracyjną" (R i c o e u r 2008: 263-278; 2003: 188-279).

Narratywistycznie zorientowani antropologowie na pytanie, która z ,prawd” interesuje ich w zbieranych opowieściach, ochoczo zakrzykną: prawda narracyjna oczywiście! Tak oczywiste jednak to nie jest, i być nie powinno, gdy bada się szczególnego typu opowieści, jakimi są świadectwa. Pytanie o ,prawdę historyczną" świadectw, ale i innych opowieści przez nich zbieranych, jest pomijane, niekiedy też odrzucane, jako - dla wyznawanego narratywizmu - nieistotne lub niewygodne. Lepiej można się poczuć, gdy się tego pytania „opowieściom” nie zadaje. Kamień z serca spada, kiedy i nas, badaczy, nikt nim nie kłopocze. Może wystarczy wtedy nazwać się konstruktywistą lub ogłosić swoją dla konstruktywizmu - choćby wybiórczą - przychylność, a nawet wdzięczność? Tak bowiem Shlomith R i m m o n-K e n a n (2002: 10-11), analizująca opowieści o chorobie, mimo iż nie chce przychylić się do wszystkich implikacji konstruktywizmu narratywistycznego, zwierza się: ,[...] za jedną z jego mocnych stron uznaję to, że uwalnia od kłopotliwego pytania o adekwatność opowieści o chorobie wobec 
rzeczywistości”. O narracjach osobistych - a za takie uznać można i świadectwa - Catherine Kohler Ries s man powie, że „są przedmiotem zainteresowania właśnie dlatego, że narratorzy interpretują przeszłość $\mathrm{w}$ historiach, nie zaś dlatego, że odtwarzają przeszłość taką, jaką była" (2001: 705; por. K o hl e r R i e s s m a n 2000: 235-236). Przywołany przez Deborah Schiffrin badacz świadectw Holocaustu, Lawrence L. Langer, utrzymuje, iż „mniej dotyczą one przeszłości, bardziej zaś sensu przeszłości w teraźniejszości" (L a n g e r 1991: 40, za: Schiffrin 2003: 540).

Zauważmy, że „prawda historyczna” przeciwstawiana bywa przy takich okazjach „prawdzie doświadczenia”. Ta pierwsza dla Margaret H. Vi c k e r s (2003: 515) jest prawdą weryfikowalną, podczas gdy ta druga daje podstawę do opowieści z życia - takiej, na jaką pozwala jego przeżywanie. Szeroko rozpisuje się o tym Arthur P. B o c h ner (2001: 154):

Co może znaczyć [...] powiedzenie, że narracja jest wierna doświadczeniu? Sądzę, że nie możemy zrobić nic lepszego, jak uznać, że prawda narracji jest prawdą pragmatyczną. Nie chodzi o to, czy narracje pokazują, jak się sprawy miały rzeczywiście, lecz raczej o to, co narracje czynią, jakie są ich skutki, do jakich celów mogą być użyte. [...] Opowiadamy, by nadać sens nam samym i naszym doświadczeniom pośród biegnącego czasu. Narracja jest zatem naszym narzędziem przywoływania znaczeń przeszłych doświadczeń, przetwarzania życia w język i odsłaniania przed nami prawdy naszych doświadczeń. Opowieść zachowuje prawdę doświadczenia $\mathrm{w}$ tym sensie, że doświadczenie ukazuje tu siebie w wymiarach poetyckich, nasyconych co prawda wielością możliwych znaczeń, lecz znaczeń szybko butwiejących, chwilowych, przygodnych [...].

Takie, przejęte misją, antropologiczne i narratywistyczne odparcie - całkowite zarzucenie lub zignorowanie - problemu ,prawdy historycznej”, naraża w badaniu świadectw na nieoczekiwaną trudność: na niekonsekwencję, na prawie nieuchwytną sprzeczność deklaracji, iż zajmuje nas wyłącznie „,prawda narracyjna”, z faktami - z naszym liczeniem się jednak z ,prawdą historyczną”. Łatwo tej zasadzki nie dostrzec, ponieważ sami ją na siebie zastawiamy. By wyjaśnić, jak do tego dochodzi i dlaczego tak trudno na nią zwrócić uwagę, zacząć muszę „od początku”, czyli - dla mnie jakieś semantyczne demarkacje to prawie zawsze początek badawczej drogi - od określenia, czym jest świadectwo.

Punktem wyjścia uczynię więc eksplikację, czyli definicję semantyczną pojęcia świadectwa jako genre'u mowy, podaną przez Annę W i e r z b i c k ą (1983: 134). Oto ta eksplikacja:

mówię to co wiem

wiem to nie dlatego że ktoś inny mi to powiedział

sądzę że nikt nie może powiedzieć że ja tego nie wiem

mówię to bo chcę żeby wszyscy wiedzieli że to jest prawda.

Tej i innym, tuż obok przez Wierzbicką umieszczonym eksplikacjom, Aleksander Wil k oń (2002: 237-239) zarzuca - oprócz nietrafności i nieoperatyw- 
ności - także „makaroniczną zawiłość”. Dopytuje więc, czy nie można by ich wysłowić prościej. Tyle że nie chodzi mu o prostotę semantyczną, którą chce osiągać zawsze swoimi określeniami Wierzbicka, lecz o prostotę i naturalność samego językowego wypowiedzenia: o możliwość zamknięcia całego tego złożonego wielosłowia w jakiejś zwięzłej i przystępnej formule definicyjnej, o uniknięcie zatem nieprzejrzystych, ciemnych i zagadkowych konstrukcji (nie ma w nich - co może niektórym przypominać logiczną łamigłówkę - znaków przestankowych). Chcąc zachować trafne intuicje semantyczne Wierzbickiej i podążyć jednocześnie za oczekiwaniami Wilkonia, eksplikację pojęcia świadectwa językowo teraz uproszczę, wziąwszy z niej to głównie, co najlepiej przystaje do mojego własnego sposobu myślenia o nim.

Najpierw będzie to idea, że świadectwo jest opowieścią o tym, co wie się nie od innych i wie się zgodnie z prawdą. Oznacza to, że - stawiam tę tezę z całą siłą - choćby najbardziej interesująca nas w świadectwach „,prawda narracyjna” pozostaje zawsze w okowach ,prawdy historycznej”. Zagadnienie wiedzy o pewnych zdarzeniach, i to wiedzy nie od innych, lecz pochodzącej z autopsji, jest zagadnieniem dostępności historii dla kogoś, kto tu i teraz jest narratorem, tam i wtedy zaś - „wewnątrz historii” - był uczestnikiem lub obserwatorem zdarzeń, które w swej opowieści relacjonuje. Jeśli świadectwo ma być świadectwem, a nie pierwszą lepszą opowieścią (byłby to zatem dla mnie wymóg gatunkowy), zawierać musi explicite bądź implicite deklarację: „byłem tam wtedy, i to, co zobaczyłem i usłyszałem, i co sam przeżyłem, właśnie tą opowieścią przedstawiam". „Byłem tam wtedy” znaczy, że byłem naocznym świadkiem zdarzeń, może jako wplątany w nie uczestnik, mogę więc być także - poprzez opowieść - świadkiem tu i teraz. To jest moje uprawnienie do opowiadania historii. Moja wiedza o tym, co się wydarzyło, nie jest wzięta od innych (lub nie tylko od nich), nie jest więc zapożyczona; to wiedza bezpośrednia: sam tych zdarzeń doświadczyłem, sam je przeżyłem, i mogę - a także chcę - zdać z nich sprawę w swojej opowieści. I faktycznie poprzez opowieść to realizuję.

Dostępność historii dla narratora, oparcie wiedzy o niej na bezpośrednim (albo bliskim takiemu) doświadczeniu, staje się podstawą stwierdzenia, że to, co się zdarzyło, jak opowiada, zdarzyło się naprawdę. Zapewnienie o prawdzie zdarzeń to równocześnie umocnienie w przekonaniu, że prawdziwa - a nie zmyślona - jest sama o nich opowieść. Zapewnienie takie jako metatekstowa część opowieści służy delikatnemu oddaleniu lub też zupełnemu i zdecydowanemu odrzuceniu wątpliwości, jakie mogły się zrodzić u jej słuchacza albo czytelnika. Siebie samego narrator przedstawia zarazem w ten sposób jako „prawdziwego świadka". Warto zauważyć, że gdy świadectwo traktuje się jako publiczne wyznanie, co się widziało i słyszało, zapewnienie o prawdziwości opowieści nabiera charakteru przysięgi, ma więc charakter poważny i dostojny - to pewnie dlatego świadectwo, szczególnie świadectwo religijne, znawcy przedmiotu zaliczają 
do gatunków używających stylu lub tonu wysokiego i języka uroczystego, podniosłego (N owak 2005; Wil k oń 2002: 266-273).

Wzięcie pod uwagę historycznej prawdy opowieści przekazywanej w świadectwie - a przynajmniej tego jej minimum, które pozwala stwierdzić, że narrator to świadek - może odpowiadać ujęciu świadectwa jako odmiany autobiografii. Autobiograficzność opowieści zawartej w świadectwie bez tego minimum jest wprost niemożliwa. Posłuchajmy, jak o tym, czym jest autobiografia, wypowiada się Jeja-Pekka R o o s (1994):

Proponuję [...], by ujmować autobiografie (różne wszak od biografii) jako narracje ze swej istoty nakierowane na rzeczywistość i prawdę, gdzie prawda jednak jest widziana z pewnego wyjątkowego, konkretnego punktu widzenia, a mianowicie z punktu widzenia autora, który zarazem jest narratorem w swojej opowieści i postrzega siebie jako takiego. Centralne dla opowieści są życiowe zdarzenia, sprawy, które się zdarzyły w jego życiu [...]. Lecz, co jest tu ważne, zdarzyły się w obecności narratora (lub pochodzą ze źródeł mu znanych i traktowanych jako godne zaufania). Autobiografia, która opierałaby się tylko, powiedzmy, na doniesieniach gazetowych, nie byłaby interesująca ani wiarygodna. [...] Ważną rzeczą w autobiografii jest zatem, aby autor znał sprawy (zdarzenia, ich związki), które pojawiły się w jego przeszłości i by chciał o nich opowiedzieć.

Czy narrator w autobiografii może czegoś z tego, co mu się przydarzyło, nie pamiętać i czy luki może wypełniać fikcją? Tak, ale nie może nie pamiętać niczego: ,[...] gdy nie pamiętasz, nie masz autobiografii [...]” - mówi R o o s (1994; patrz R o o s 2003: 31-32).

Dostępność historii dla narratora, choćby owo minimum ,prawdy historycznej” w jego opowieści, potrzebne jest badaczowi, jeśli tylko poprzez narratora jako świadka, lub przede wszystkim przez niego, sam chce mieć dostęp do historii. Mówiąc prościej, chodzi więc o to, że samemu badaczowi potrzebna jest pewność, że narrator studiowanej przez niego opowieści „był tam i wtedy”, że to, iż tam wtedy był, jest prawdą, i że wobec tego może on być świadkiem historii - ,prawdziwym świadkiem”. Zwłaszcza w kwestii tego minimum badacz antropolog może gotów jest porzucić (jeśli ten go wcześniej bez reszty pochłaniał, oczywiście) swój radykalny narratywistyczny konstruktywizm i przyjąć - ograniczone do owego minimum i dalej niesięgające - stanowisko całkowicie realistyczne. Owszem, zająć się chce światem samej opowieści i „prawdą narracji”, odbiegającą nawet od „prawdy historii”, chce wszakże mieć przeświadczenie, że narrator jest tym, za kogo się podaje, tzn. że jest on rzeczywiście świadkiem historii. Badacz oczekuje więc, że rzeczywiście z Kresów Wschodnich wywieziono narratora na Syberię, gdy był dzieckiem, że rzeczywiście był on więźniem Gułagu, że ktoś z jego rodziny rzeczywiście zginął w Katyniu, że jako Łemko rzeczywiście został deportowany z Łemkowszczyzny do Białego Boru, że rzeczywiście urodził się i spędził dzieciństwo przed wojną na Bałutach itd. Badacz oczekuje, ale i sprawdza - na podstawie źródeł innych niż sama opowieść - że określona przez takie minimum rama historyczna jest ramą trzymającą się historycznej 
prawdy. Czyż nie na tym polega „odpowiedni” dobór informatorów do badań: odsianie tych, którzy ze swoimi opowieściami nie zmieściliby się w tej ramie, i pozostawienie wyłącznie niewątpliwych świadków historii? Co w tej historycznej ramie umieszcza, opowiadając w świadectwie narrator, już poza samo minimum wykracza i może być analizowane i interpretowane nawet wyłącznie - zwłaszcza przez antropologa pragnącego swoim ujęciem i warsztatem odróżnić się od „tradycyjnego" historyka - jako „prawda narracyjna”.

Z powodu niespełnienia warunków określonych przez historyczne minimum, świadectwa okazują się niekiedy pseudoświadectwami. Narrator mówi: „byłem tam wtedy", lecz jest to nieprawda. Tak mówił w swoich wspomnieniach z dzieciństwa spędzonego w nazistowskim obozie śmierci Binjamin Wilkomirski, tyle że po sprawdzeniu stało się jasne, że są one zmyśleniem, autobiograficzną fikcją. Wyglądała ona nadzwyczaj wiarygodnie: niektóre opisywane w niej fakty i zdarzenia były po prostu prawdziwe (bo potwierdzone przez niezależne źródła), inne - wielce prawdopodobne; za nieprawdziwy jednak uznać trzeba było w końcu fakt podstawowy: Wilkomirski nie jest w ogóle tym, za kogo się podaje, nie jest przeto świadkiem historii, o której opowiada. Nie jest w każdym razie świadkiem w znaczeniu, o które tutaj chodzi. Zastanawiając się nad „fenomenem Wilkomirskiego", podkreślił Jeremy D. P o p k in (2002: 18), jak wielką rolę odegrali badacze „okazujący szczególne współczucie osobom, które przeżyły Holocaust, w przerobieniu opowieści Wilkomirskiego na «autobiografię»".

Inną myślą, jaką wydobywam z eksplikacji podanej przez Wierzbicką, jest ustalenie, że świadectwo to opowieść o tym, o czym chce się mówić, żeby wszyscy wiedzieli, że to jest prawda. Świadectwo, cokolwiek by powiedzieć o zamiarze jego lektury przez badacza, od narratora wymaga zaangażowania w ,prawdę historyczną". Ma to być zaangażowanie osobiste i niepowierzchowne, całą osobą opowiedzenie się „za” lub też „na rzecz” tej prawdy. Świadek, właśnie przez to, że opowiada się za czymś, chcąc relacjonować daną historię i chcąc, by była ona znana wszystkim jako prawda, jest - jak pisze Ricoeur w swojej pracy poświęconej świadectwom, zwłaszcza religijnym - „kimś cokolwiek innym niż dokładny, nawet skrupulatny narrator" (R i c o e u r 1980).

Poświadczenie pewnej historycznej prawdy to - jak przed sądem - sytuacja próby, czasem nawet próby, w której wiele się ryzykuje: utratę „twarzy”, ale i życia. Ricoeur pisze: „Owo zaangażowanie, owo zakładane przez świadka ryzyko, odbija się na samym świadectwie, które - odpowiednio do tego - oznacza coś innego niż proste opowiedzenie o tym, co się widziało" (R i c o e u r 1980). Wynika $\mathrm{z}$ tego, że w świadectwie opowiedzenie czegoś jest zawsze opowiedzeniem

4 Od niedawna dostępne jest polskie wydanie tej pracy (R i c o e u r 2011). Wszystkie przytoczenia - w moim własnym tłumaczeniu - pochodzą tu z tekstu angielskiego. Fragment cytowany w tym miejscu oraz dalsze cytowane przez mnie fragmenty znaleźć można w polskim wydaniu na s. 24. 
się za tym, o czym się opowiada. Śmierć, o której mówi Ricoeur, nie musi być dosłowna, a jeśli nawet, pamiętać warto, że męczennik to w grece tyle, co mártys, czyli wprost świadek. Czasem chodzi tu tylko albo aż o metaforyczną ,śmierć dla starego świata" i - jak przy świadectwach konwersji, zwłaszcza radykalnej o „skok w inny świat”. Gdy świadectwo opowiada pewną historię, i jest to historia wielkiej życiowej przemiany, stary topos śmierci i odrodzenia do nowego życia objawia w nim w pełni swoją żywotność. Słusznie zauważa ks. Grzegorz D z i e w u ls ki (2002b: 1189), iż zaangażowanie pozwala uwypuklić „,uprzywilejowany status wobec osób i wydarzeń”, o których w świadectwie się opowiada. Status ten zapewnia świadkowi dynamizm i ofensywność w przekazywaniu prawdy historii. Zapewnia jednak - tu wtrącić wypada antropologiczne zastrzeżenie - tylko w sytuacji kulturowej, w której osoba zaangażowana, bo włączona w zdarzenia, szczególnie ta, której one bezpośrednio dotyczą, może o nich opowiedzieć (W e j 1 and 2004: 62-63).

Krok już jednak do ujawnienia w ten sposób jeszcze jednego głębokiego wymiaru świadectwa ukazanego eksplikacją Wierzbickiej. Jak utrzymuje Jean Guitton, mając taki status, ,świadek angażuje się osobowo w swoje świadectwo i chce w orbitę tego zaangażowania wciągnąć tych, wobec których świadczy" (Rusecki 2002: 1331). Próbując wciągnąć innych w orbitę zaangażowania, świadectwo nie tylko zatem zdaje sprawę z tego, co się zdarzyło, nie tylko więc relacjonuje historię, lecz również zaprasza, apeluje, wzywa do jej przyjęcia jako prawdy. W świadectwach religijnych ton ten bywa tonem proroka nawołującego do otwarcia oczu na znaki, czyli dziejącą się historię.

\section{HERMENEUTYKA ŚWIADECTWA: „TUBYLCZA EGZEGEZA” A PUŁAPKA ANTROPOLOGICZNEJ NAIWNOŚCI I PYCHY}

Trzecia pułapka powstaje ze zmieszania antropologicznej naiwności z antropologiczną pychą. Nie dotyczy ona jedynie badacza świadectw (a świadectw religijnych, w tym charyzmatycznych, w szczególności), lecz w jego wypadku zwłaszcza gdy w swoje „naukowe” przedsięwzięcie, nie chcąc rozerwać się na strzępy, angażuje też w sposób mniej lub bardziej widoczny „osobiste” przekonania religijne - osunięcie się w nią bywa bolesne i wywołuje dokuczliwy kacenjamer. Bo oto naiwność (to tylko eufemizm) podsuwa badaczowi myśl, że wyłaniający się z zebranych przez niego świadectw obraz świata i człowieka, głównie w skali „opowiadającej wspólnoty” (a zatem np. wspólnoty charyzmatycznej, i to jak najszerzej pojętej, usuwającej koordynaty miejsca i miarę czasu), ma walor uniwersalny. To więc, co ustalił „tu i teraz”, miałoby się odnosić do tego samego rodzaju opowieści, czy też świadectw „wszędzie i zawsze”, albo przynajmniej - w wariancie ostrożniejszym - nie powinno się kłócić z tym obrazem świata i człowieka, który gdzieś po sąsiedzku i niedawno lub nawet gdzieś dalej i przed laty, ale 
przecież w „takich samych” warunkach kulturowych, wydobył z nich ktoś inny, dajmy na to uznany autorytet $\mathrm{w}$ zbieraniu oraz analizie i interpretacji świadectw charyzmatycznych. Kiedy wszak taka niezgodność się przytrafi i kiedy antropologiczna hybris weźmie górę, wielkiemu autorytetowi możemy chcieć wytknąć metodologiczną skazę, coś, co - po jego stronie, nie po naszej - sprawia, iż wyniki z „takich samych” badan „takich samych” świadectw, przedstawianych w ,takich samych", choć lokalnych wspólnotach, tak istotnie się różnią - choćby to był znaczący szczegół. Jeśli jako badacze roztropni i pełni pokory nie wpadniemy w tę pułapkę, czeka nas coś zapewne bardziej szlachetnego, ale niełatwego: zagadka, którą wypadałoby $\mathrm{z}$ honorem rozwikłać. To zaledwie jedna z odmian zagadek, na jakie natrafia w terenie antropolog, o czym tak ciekawie pisał Jack K a t z (2001: 448-452; patrz We j1 and 2010a: 166-167; 2010b: 150-152). Pociecha w tym jednak niewielka, gdy zagadka przemienia się w tajemnicę, a żadne „szczęśliwe odkrycie" nie pozwala się z nią uporaćs.

Skłonny, najpierw z niespodziewaną dla siebie samego zadziornością, do walki o „swoje”, gotów więc od razu stanąć w szranki - we własnym badaniu świadectw charyzmatycznych skonfrontowałem się w ten sposób z Thomasem J. Csordasem: każdy z nas, studiując opowieści katolickich charyzmatyków - on z Nowej Anglii, ja z rodzinnej Łodzi - wyczytał różne pojęcia osoby (C s o r d a s 1994: 39-45). Istotne - i prawie oburzające - było dla mnie przede wszystkim to, że ustalone przez niego pojęcie osoby nie zgadzało się z moim własnym rozumieniem sprawy jako katolika. Co więcej - pewien byłem, że nie zgadza się z „ortodoksyjnie poprawnym” rozumieniem osoby ludzkiej wśród „moich” charyzmatyków. Na szczęście ochłonięcie pozwoliło przemienić tę zawadiacką konfrontację w metodologiczną zagadkę: zmusiło do przyjrzenia się dokładniej antropologicznej praktyce Csordasa i mojej własnej.

W analizie i interpretacji opowieści można brać pod uwagę ich wewnętrzny hermeneutyczny wymiar albo można go pomijać, narzucając im hermeneutykę przyjętą przez siebie. Nie zważać na sugestie lub wyraźne nakazy interpretacyjne płynące z samych tych opowieści to nie ufać „tubylczej egzegezie”: przyjmować wobec niej postawę nieufności bądź ją nawet odpychać, uznawszy np. za naiwnie religijną lub prymitywnie mityczną, jednym słowem - „nienaukową" ${ }^{6}$. To w końcu obrać egzegezę własną: w najgorszym razie - najgorszym dla „tubylczej egzegezy” - całkowicie wypierającą oryginalne „momenty hermeneutyczne”, w najlepszym zaś - dla „tubylczej egzegezy” - pozostawiającą ją nienaruszoną,

5 Nawiązuję tutaj do znanego w nauce efektu serendipity (M e r t o n 1982: 170-174; W e j1 and 2010a: 166).

${ }^{6}$ Wyrażenia „tubylcza egzegeza” używam jak Csordas, obaj zaś podążamy w tym względzie za Victorem W. Turnerem, który to wyrażenie wynalazł i wprowadził do pisarstwa antropologicznego (jako native exegesis, C s o r d a s 1994: 61). Pojawia się ono (choć thumaczenia bywają rozmaite) w pracach T u r n e r a wydanych po polsku, np. w książkach z lat 2006, 2010. 
ale i nieobjętą żadną refleksją, bądź co najwyżej refleksją zalążkową. W takim wypadku badacz jakby „tubylczej egzegezy” nie dostrzega, zamyka na nią oczy - wystarcza mu egzegeza własna, jeśli zaś ją dostrzega - poświęca jej niewiele uwagi i studiuje raczej pobieżnie. To on przecież nadaje opowiadanym historiom znaczenie, on jest, bo chce być, dla opowieści „demiurgiem sensu”. Badacz, o którym tu mówię, to zazwyczaj zewnętrzny obserwator, a nie uczestnik „tubylczej kultury". Przy takiej postawie wchodzi on w krąg hermeneutyczny nie tylko z własnym nierewidowalnym przedrozumieniem opowieści (w którym niekoniecznie tkwi przesłanka, że to, co mają na myśli narratorzy, jest sensowne), ale i z własnym metodologicznym przesądem. Przesąd ten polega na tym, iż towarzyszące opowieściom, w nich samych zawarte, objaśnienia głębokiego sensu zdarzeń i komentarze tłumaczące powody poddania mu interpretacji nie tylko chwilowego doświadczenia, ale i całego przeszłego życia, nie są warte nic lub są warte niewiele. Jako zewnętrzny obserwator woli on zatem stosować egzegezę zewnętrzną, tzn. hermeneutykę - sposób wyławiania sensu w interpretowaniu zdarzeń - opartą na wyjaśnianiu za pomocą pojęć zewnętrznych, by użyć określenia Petera Abella. Pojęcia zewnętrzne - jak łatwo się domyślić - to pojęcia wprowadzane przez badacza niezależnie od tego, jakie pojęcia stosują ludzie, których opowieściami jest zainteresowany, pojęcia wewnętrzne natomiast to „te, którymi posługują się same osoby działające, by opisać i wyjaśnić swe zachowania, działania i środowisko społeczne". Abell roztropnie zauważa, że granica między nimi „nie zawsze jest zupełnie ostra”, szczególnie gdy badacz „znajduje się w swego rodzaju wspólnocie” z tymi, których obrał sobie za „przedmiot badania” (A b e 1 1975: 45) $)^{7}$.

Kwestia, którą teraz roztrząsam, powstaje wszak tylko wtedy, gdy oprócz sensu powierzchniowego przedstawianych faktów i zdarzeń, dostrzeże się ponadto zawarty w samych relacjach sens głęboki, ich - jak by powiedział Abell (1975: 50) - wewnętrzne ,głębokie rozumienie”. To ów „sens”, a nie tylko chwytana fabułą „historia”, miałby być dostępny narratorowi, choćby w świadectwie religijnym. Hermeneutyczny wymiar takiego świadectwa, jako ,istotny dla tożsamości świadka”, zdaniem Dziewulskiego polega na „szczególnej więzi jego osoby z poświadczanymi wydarzeniami i prawdami, dzięki której ma on dostęp do ich właściwego, czyli nadprzyrodzonego, religijnego znaczenia" (D z i e w u 1 ski 2002a: 775). Sens religijny opowiadanej w świadectwie historii to właśnie jej sens głęboki, ściśle biorąc - jeden z głębokich sensów, jakich można by się

7 Pisząc to czterdzieści lat temu, i chyba nawet nie przeczuwając swojego późniejszego zainteresowania (szczególnie jednak, bo matematycznie pojętymi) narracjami i „wyjaśnianiem poprzez narracje", Abell wyróżniał, dodawszy jeszcze podział pojęć na wyjaśniane i wyjaśniające, trzy logicznie możliwe podejścia eksplanacyjne, czyli sposoby rozumienia widzenia świata przez tubylczych aktorów (A b e 11 1975: 46-52). Nie powinny one pozostać antropologom nieznane, ich omówienie pomijam tu jednak z oczywistej potrzeby zachowania umiaru. 
w historii doszukiwać. Nie znaczy to, że doszukuje się ich wszystkich w swojej historii świadek. Świadek składający świadectwa religijne będzie zwykle sens religijny traktował jako jedyny, właściwy; może też wprawdzie brać w rachubę inne jej głębokie znaczenia, lecz oparte na nich interpretacje zechce zapewne prezentować jako nieudane, bo niechwytające istoty rzeczy i niedocierające do prawdy, nietrafne zatem hipotezy. To właśnie dzięki sensowi religijnemu nada historii niepowtarzalną interpretację, docierając swoją hermeneutyką do czegoś $\mathrm{w}$ istocie poza samą historią. Przekroczy ją więc w poszukiwaniu sensu, ukrytego dla prostego „czytania” zdarzeń, wyjaśni ją tym, czego na powierzchni - bez tego przekroczenia - w ogóle nie widać, np. działaniem Boga w swojej codzienności. Świadek będzie przy tym z siłą przekonywał, że nie jest to sens zapożyczony ani wydumany, ale oparty na jego osobistym doświadczeniu.

Idea dostępności sensu historii dla narratora nie wymaga, by sens ów był mu dostępny „tam i wtedy”, tzn. w czasie dokonujących się zdarzeń. Będąc pośród nich, mógł on wprawdzie dostrzec coś niezwykłego, mógł nawet doświadczyć epifanii - poczucia, iż dotyka „czegoś więcej” niż w zwykłym, codziennym doznawaniu życia, że przebywa na skraju tajemnicy czy zagadki. Zwykle jednak na zrozumienie tego doświadczenia - i na ogarnięcie go pogłębiającą refleksją - na dotarcie do „prawdziwego" sensu zdarzeń, potrzeba spokojnego oddalenia, skupienia i „bicia serca w ciszy”. To zresztą także czas nieodzowny, by doświadczona historia, a szczególnie to, co w niej niezwykłe, niecodzienne, wyjątkowe, mogło znaleźć dla siebie narracyjną formę: by więc mogło ułożyć się w „,dobrze skonstruowaną" opowieść. Głęboki sens opowiadanej historii będzie w takiej narracji albo wyłaniał się równolegle z relacjonowanymi zdarzeniami, albo też pojawi się nagle na początku opowieści, albo też stanie się kończącym morałem czy puentą. Tak czy owak w narrację się wplecie - w próbie wyrażenia głębokiego, zwykle bardziej ogólnego niż szczegółowa historia, sensu, w próbie, którą - o czym wspominałem - za van Dijkiem nazywam eksplikacją ${ }^{8}$. Eksplikacja sensu to jawny, widoczny wprost w tekście opowieści rezultat działania „tubylczej egzegezy”. Nie twierdzę - pamiętając o kulturowym zagnieżdżeniu świadectw, jakie sam zbierałem - że nie jest to egzegeza „znaleziona” przez narratora. Obstaję jedy-

8 Użycie przeze mnie tego słowa - co właśnie odkrywam - może być mylące dla tych, którzy mają z nim mało do czynienia, ponieważ nie zajmują się ani analizą logiczną, ani semantyczną, nie sięgają też do prac poświęconych strukturze i gramatyce opowieści, jej rozbiorowi na „elementy funkcjonalne” itd. Występuje więc ono u mnie i jako inna nazwa dla „definicji semantycznej” (gdy powołuję się na Wierzbicką), i jako nazwa odnosząca się do pełniącego funkcje objaśniające fragmentu opowieści czy też opowiadania (gdy sięgam do van Dijka). Znaczenie podstawowe jest zawsze to samo, bo eksplikacja to ogólnie tyle, co objaśnienie, wyjaśnienie: raz jednak chodzi o objaśnienia lub precyzacje pojęciowe wprowadzane przez badacza, innym razem o objaśnienia, tłumaczenia zdarzeń, jakie narratorzy podają w swoich opowieściach (wraz z pytaniem, o ile korespondują z nimi ,eksplikacje”, czyli - o co przecież chodziło Abellowi - wyjaśnienia przyjmowane przez czytającego je antropologa). 
nie przy tym, że „znajduje” on swoją hermeneutykę wśród sposobów rozumienia podsuwanych przez wspólnotę, interpretującą historie gromadzące się i przetaczające przez czas „kaskadą świadectw”"

Wzorcowych sposobów interpretacji wspólnota proponuje ledwie garść, niekiedy wręcz sprzyja jednej „obowiązującej wykładni” wszelkich opowiadanych historii lub historii określonego typu. W takich sytuacjach łatwiej jest o użycie, w charakterze eksplikacji, gotowych lub prawie gotowych formuł. W dyskursie wspólnoty charyzmatycznej formuły eksplikujące sens historii, np. sens zdarzeń przywodzących do cudownego uzdrowienia z ciężkiej choroby i powiązanego z nim uzdrowienia duchowego, często splatają się z formułami modlitewnymi lub same nabierają brzmienia modlitewnego, zwłaszcza na krańcach świadectw, zyskując wtedy jeszcze znaczenie wyznania wiary.

Zarówno Csordas, jak i ja chcieliśmy uwzględnić „tubylczą egzegezę”. Obu nam daleko wszakże było (i jest) do łatwego optymizmu, że po pierwsze, pojawia się ona zawsze i wszędzie, a więc że pojawia się również w każdym wspólnotowym, rytualnym lub pararytualnym, performansie albo w komentujących go opowieściach, a po drugie, że jest ona - gdy już się pojawia - bezpośrednio przez badacza uchwytna, jakby wyłożona na talerz. Eksplikacje w samych świadectwach to jedynie cząstka dyskursu wspólnotowego ujawniającego tę egzegezę. Csordas mówi, że do uchwycenia tego, jak rozumieją badani przez niego charyzmatycy zdarzenia cudownych uzdrowień, trzeba uwzględnienia całego ,systemu uzdrawiania”. Przestrzeń antropologicznej penetracji musi być przeto bardzo rozległa. Przywołując podejście już dobrze znane, powiada w związku z tym, że

antropologiczne rozumienie uzdrowienia wymaga podwójnej hermeneutyki. Jest to hermeneutyka hermeneutyki, interpretacja interpretacji. Stosujemy nasze interpretacyjne strategie [...] do interpretacyjnych strategii ludzi, których kultury badamy (C s o r d a s 1994: XI).

Zgodnie z tą tezą, „tubylcza egzegeza” musi być zawsze uwzględniana, lecz - tego się żąda od antropologa - nad nią musi się nadbudowywać jego własna hermeneutyka. „System uzdrawiania”, uzasadnia Csordas, jest bowiem refleksyjny, potrzeba przeto nie monologu antropologa, lecz „dialogu refleksyjności” (C s o r d a s 1994: XI-XII).

Csordas, do czego się z chęcią przyznaję i co bez tego łatwo spostrzec, stał się dla mnie niewątpliwym punktem odniesienia, może wręcz wzorem godnym naśladowania, bo w tych poglądach niezwykle mi bliskim. Czy mogę pominąc to, że nie podążam jak on za fenomenologią Maurice'a Merleau-Ponty'ego? Wolę zademonstrować, na czym polega - Csordasa i mój - szacunek dla „tubylczej egzegezy". Każdy z nas go przejawia, i właśnie dlatego wyczytujemy ze świadectw charyzmatycznych różne pojęcia osoby. Studium „systemu uzdrawiania” każe oczywiście brać świadectwa w całym ich hermeneutycznym kontekście. Na

9 Wyrażenie to pojawiło się już we wcześniejszej mojej pracy (W e j 1 a n d 2004: 68). 
kontekst ten składają się i wypowiedzi komentujące świadectwa, i wyprzedzające je lub następujące po nich teksty homilii, czytań biblijnych, referatów, także publikowanych artykułów i książek, np. - jak w Łodzi - tekstów, w tym części spisanych świadectw, które znaleźć można we wspólnotowym piśmie „Szum z Nieba”. Innymi słowy, kontekst ten wytwarza się w bogatym, wieloskładnikowym dyskursie wspólnoty. Tworzą go również kontakty z innymi wspólnotami. Jednocześnie widać, jak oba konteksty - ten rekonstruowany przez Csordasa i ten rekonstruowany przeze mnie - muszą się co do treści nie pokrywać, jak odmiennych muszą dostarczać interpretacyjnych podniet i reguł, skoro na ich podłożu wyrastają - i to właśnie stanowi metodologiczną „tajemnicę” - różne pojęcia osoby.

Jakie pojęcie osoby wyczytał więc C s ordas (1994: 39) - dzięki własnej antropologicznej hermeneutyce - z zebranych przez siebie świadectw i z ich hermeneutycznego kontekstu? Oto jego konstatacja podstawowa: „Istotne dla systemu charyzmatycznego uzdrawiania jest pojęcie osoby jako trójczęściowego compositum ciała (body), umysłu (mind) i ducha (spirit)". A teraz konsekwencje tej konstatacji dla wydzielanych typów uzdrowienia:

Odpowiedni dla każdego komponentu trójczęściowej osoby jest typ uzdrawiania: uzdrowienie fizyczne choroby cielesnej (bodily illness), uzdrowienie wewnętrzne niedomagania emocjonalnego (emotional illness) czy strapienia (distress) oraz uwolnienie od niekorzystnych wpływów złych duchów (evil spirits). [...] Komponenty trójczęściowej osoby splatają się holistycznie w, jak mówią, ,pneumopsychosomatycznej” syntezie (C s o r d a s 1994: 40).

Jakie wobec tego pojęcie osoby udało się wyczytać ze świadectw charyzmatycznych i ich kontekstu mnie samemu? Pojęcie osoby, czy też człowieka jako osoby, nie jest - wedle moich ustaleń - oparte na prostej, jak u Csordasa, trychotomii: ciała, umysłu i ducha. Nie pokrywa się z nią zwłaszcza wtedy, gdy słowo „umysł” zastąpić słowem „dusza” albo słowem „psychika”. Trójczęściowe compositum w sprawozdaniu C s o r d a s a (1994) to, jak się wydaje, całość złożona $\mathrm{z}$ równorzędnych, przystających do siebie składników. Jeśli nawet miałyby tu wystąpić trzy komponenty, to - moja interpretacja interpretacji ku temu zmierzała - nie na zasadzie prostej równorzędności, i może w ogóle nie za zasadzie prostego składania się w całość. Owszem, w niektórych tekstach znanych wspólnocie mówi się o trzech składnikach, np. jeden z paragrafów rozdziału Uzdrowienie $i$ wyzwolenie w książce Monique Hé b r a r d (1994) uderza trychotomią: „Ciało, duch i dusza".

Lektura tych tekstów kazała mi raczej przyjąć, że podstawowa dla pojęcia osoby jest tu dychotomia ciała i duszy, oraz że komponent „ducha” jest w nich zapewne rozumiany nie po prostu jako trzeci, nieoddzielny od innych, składnik compositum. Długo by opowiadać o dalszych moich dociekaniach: o tym, jak pilnie począłem studiować najpierw dość przystępne wprowadzenia, potem jednak ogromnie poważne dzieła teologiczne, oraz jak stopniowo odkrywałem przyczynę swojego buntu przeciw trychotomii i odczucia, że jest „niepoprawna”, niewierna 
katolickiej, czy w ogóle chrześcijańskiej ortodoksji (okazało się, że - mając spore ugruntowanie $\mathrm{w}$ hermeneutyce biblijnej - doktryna trychotomizmu często sprowadzała na manowce bliskie herezji). Z intelektualną odsieczą przyszedł mi wreszcie, nie wiedzieć jednak czemu tak późno przeze mnie w tej sprawie otwarty i przewertowany, Katechizm Kościoła Katolickiego. W jednym z jego passusów znalazłem i usprawiedliwiające „moich” charyzmatyków, i uspokajające mnie samego wyjaśnienie:

Niekiedy odróżnia się duszę od ducha. W ten sposób św. Paweł modli się, aby „nienaruszony duch wasz, dusza i ciało... zachowały się na przyjście Pana” (1 Tes 5,23). Kościół naucza, że rozróżnienie to nie wprowadza jakiegoś dualizmu w duszy. „Duch” oznacza, że człowiek, począwszy od chwili swego stworzenia, jest skierowany ku swojemu celowi nadprzyrodzonemu [...] (Katechizm ... 1994: 93) ${ }^{10}$.

Mało mi wciąż było jednak pewności, póki nie trafiłem na prawosławnego teologa Paula Evdokimova i z jednej z jego prac nie mogłem wypisać takich to rozjaśniających ostatecznie moją hermeneutykę hermeneutyki - słów:

To, co cielesne i to, co psychiczne zawiera się w sobie nawzajem, a każde kieruje się własnymi prawami; to, co duchowe nie jest trzecią z kolei sferą, lecz kategorią, wyrażającą się przez psychikę i cielesność oraz czyniącą je duchowymi (E v d o k i m o v 1996: 27).

Oznacza to - wytłumaczyłem sobie - że i ciało, i dusza (psychika, umysł) mogą stać się i być duchowe, mogą osiągnąć pewną szczególną jakość (kategorię). Na czym to polega? Niech ponownie odezwie się Evdokimov (1996: 27-28): „Jak chce św. Augustyn, człowiek może uczynić cielesnym nawet swego ducha, a duchowym - nawet swoje ciało. Duch jest przyczółkiem, który wchodzi w kontakt i uczestniczy w rzeczywistości nadprzyrodzonej”. To również przyczółek, który mogą zaatakować „złe duchy” - te wypędzane dzięki charyzmatycznej posłudze uwolnienia i w ogóle dzięki wszelkim egzorcyzmom. „Złe duchy” atakują i duszę, i ciało - spętują całego człowieka w jego duchowym wymiarze.

Na metodologicznie ważne, ale i antropologicznie ciekawe pytanie, skąd biorą się różnice w rekonstruowanych przez Csordasa i przeze mnie pojęciach osoby, jakimi posługują się charyzmatycy z jego i moich badań, wciąż nie mam odpowiedzi dobrej, tzn. takiej, która by zadowalała od strony teorii i przekonywała od strony empirycznej, terenowej praktyki. Jeśli założyć, że obaj dołożyliśmy wszelkich starań, by odczytać „tubylczą egzegezę”, jeśli więc przyjąć nie tyle może naszą „przezroczystość” jako hermeneutów, ile raczej naszą zdolność wniknięcia - każdego, jak się okazało, w inny - horyzont pojęciowy badanej wspólnoty charyzmatycznej, to dostrzeżone różnice wypadnie przypisać samym tym horyzontom,

${ }_{10}$ Na odwrocie strony tytułowej Katechizmu... (1994) umieszczono wyjaśnienie: „Teksty Pisma Świętego cytowane są według IV wydania Biblii Tysiąclecia, Pallotinum, Poznań-Warszawa 1984. Sigla biblijne według Biblii Tysiaclecia. 
a zatem odmienności charyzmatycznych wspólnotowych „systemów uzdrawiania". Czy to jednak tylko lokalne warianty w obrębie jednego katolickiego ruchu charyzmatycznego? Czy może niezgodności mające swoje historyczne korzenie i usprawiedliwione odmiennością szerszego kulturowego kontekstu? Kryjąca się za tym brakiem odpowiedzi „tajemnica” to może, jak lubimy mówić, zachęta do dalszych przemyśleń i badań - „tajemnica” wymuszająca na mnie gorączkowe poszukiwanie wyjaśnień i stanowczo przyzywająca do naukowej pokory.

\section{OPOWIEŚCI, KTÓRE PODAJĄ SIĘ ZA ŚWIADECTWA - PULAPKA GATUNKÓW PODSTAWIONYCH I ANTROPOLOGICZNA HERMENEUTYKA PODEJRZEŃ}

Czwartą i ostatnią pułapkę, o której chcę tu wspomnieć (bez pretensji do tego, że powiem o wszystkich), tworzy złudne przeświadczenie o całkowitej zgodności między badaczem i „tubylcami”, gdy on i oni używają słowa „świadectwo” na oznaczenie pewnej szczególnej narracyjnej formy dyskursu. W moim własnym badaniu charyzmatycznych świadectw uzdrowienia problem pojawił się wtedy, gdy zrozumiałem, iż przyjęta przeze mnie „teoretyczna” eksplikacja pojęcia świadectwa jest zbyt wymagająca w stosunku do wielu - jak je określa wspólnota charyzmatyczna - „świadectw”. Z żalem stwierdzałem, że w wielu ,świadectwach” brak jest „dobrze zbudowanej opowieści”, że czasem samemu uzdrawianemu przychodzi publicznie powiedzieć ledwie parę słów, i tak zamkniętych w powszechnie znane formuły modlitewne, że zamiast w miarę prostej i łatwej do analizy opowieści jednej osoby trafiają się współopowieści, nawiązujące do siebie i często wystrzegające się powtórzeń już „znanych” faktów, że niektóre opowieści są rozwinięciem poprzednich, już kiedyś przedstawianych (i to niekoniecznie temu samemu zgromadzeniu), że świadectwa tej samej osoby - w jej pobudzeniu misyjnym - właściwie się nie kończą itd. Nie mogłem nie zauważyć, że słowo „świadectwo" jest obecne w dyskursie badanej wspólnoty i że pełni w nim ważną konstrukcyjną rolę. Używa się go w niej, by mówić, iż w „godzinie świadectw” składane są właśnie świadectwa, że nie wygłasza się zatem wypowiedzi o innym - to oczywiście mój „uczony” język - komunikatywnym sensie. Także same świadectwa za pomocą tego słowa zobowiązują się wobec słuchaczy (i późniejszych czytelników), że są tym, za co się podają. Dopiero takie zobowiązanie wewnątrz nich oraz płynące z zewnątrz potwierdzenie - „tak, to są prawdziwe, autentyczne świadectwa!" - otwiera na dzielenie się nimi.

Wypowiedzi (metawypowiedzi) W rodzaju: „chcę podzielić się świadectwem...” czy też „posłuchajmy świadectwa”, albo „to jest moje świadectwo, którego wysłuchaliście” oraz „wygłosiła nam swoje świadectwo..." noszą charakter performatywów dyskursu, tak jak określiła je Aleksandra Żuk k ow sk a 2002: 28-37). Performatywy dyskursu formują ramę, która pozwala odróżnić (i objąć) 
świadectwa religijne (nazywane tu po prostu „świadectwami”, „świadectwami wiary" lub podobnie) od innego rodzaju świadectw, w szczególności pozwalają rozpoznać, iż są one świadectwami chrześcijańskimi (ewentualnie z jakimiś jeszcze uszczegółowieniami - „katolickimi”, „charyzmatycznymi” itp.). Sprzyjają ponadto zrozumieniu, czym nie jest takie świadectwo, przede wszystkim więc, iż nie jest to tylko realizacja chęci publicznego oznajmienia, co „się zdarzyło naprawdę”. Wyraża ono określoną postawę, życiową orientację (po nawróceniu religijnym ma to sens najwyraźniejszy): „Każde świadectwo postawy jest - jak pisał Andrzej Grzegorczyk - świadectwem uznania jakichś wartości” (G r z e g o r c z y k 1983: 67). Dzielenie się świadectwami wymaga zatem postawy świadka, tutaj akurat „świadka Chrystusa”. Wymaga mówienia prawdy i zawierzenia „swojemu najlepszemu rozumieniu prawdy" (Gr z e g o r c z y k 1983: 67), ale również rzeczywistej zgody na tę prawdę, zgody zaangażowanej, opowiadającej się za tą prawdą w jakimś moralnym horyzoncie, np. więc religijnym, tutaj - chrześcijańskim.

Performatywy dyskursu pomagają ustalić, jak badana wspólnota rozumie słowo „świadectwo”, opierając się na nich można by nawet mówić, że wspólnota rozpoznaje pewne dyskursywne formy wypowiedzi jako świadectwa i umie - ,intuicyjnie" wskazując ich cechy gatunkowe - odróżnić świadectwa od wypowiedzi o zdecydowanie lub nieco innym charakterze, a więc od wypowiedzi pod wieloma względami pokrewnych. Ponieważ dyskurs we wspólnocie charyzmatycznej - tak jak dyskurs we wspólnocie naukowej - pełni rolę tutora (We j 1 a n d 2010a: 155-156) i ponieważ zazębia się przy wielu okazjach z dyskursem teologicznym, biblistycznym, także filozoficznym, literackim itd., rozpoznaniu świadectwa asystować może identyfikacja - jako różnych od niego - takich wypowiedzi, jak wspomnienie autobiograficzne, relacja z przebiegu choroby, intymne wyznanie czy opis przeżycia. Może być ono jednak (co raczej zaburza badaczowi ostre widzenie) z tymi formami utożsamiane lub na ich wzór narracyjnie kształtowane. Zauważmy, jak silnie na to zazębianie się gatunków wpłynęła najdawniejsza tradycja ustna w chrześcijaństwie:

[...] pierwotny gatunek opisu przeżycia odgrywał ważną rolę już w tradycji ustnej, ponieważ ten, kto w tej formie zdawał relację ze swego przeżycia, dawał zarazem o nim świadectwo. Później opis przeżycia, traktowany jako literacka forma stylistyczna, wykształcił się [...] w rodzaj sprawozdania (L a n ge r 1995: kol. 898).

Łatwo wybrnąc z tego kłopotu, deklarując operowanie szerokim i swobodnym, a zatem nieprzesadnie różnicującym pojęciem świadectwa. Jeśli nie stoi za tą deklaracją poważna argumentacja metodologiczna, jest ona po prostu sprytnym, chociaż bez trudu rozpoznawalnym wybiegiem - objawiającą bezradność ucieczką od brania w rachubę konceptualnej złożoności języka „tubylców” i od szukania korespondencji z nim własnego języka. Na podstawie moich doświadczeń wnoszę, że mimo wstępnych prób definicyjnych i mimo wysiłków wsłuchiwania 
się we wspólnotowy dyskurs oraz wydobywania z niego zachęt do rozpoznawania ,świadectw” jako świadectw, tropienie i odnajdywanie tej korespondencji ma pełną wzlotów i upadków dynamikę, w sporej zaś mierze zależy od tego, o ile badaczowi udaje się - a to stara antropologiczna idea - wejść w samo „środowisko życia” świadectw, o ile chce i może „pożyć” razem z ,tubylcami”: uczestniczyć w ich ,świadczącej” codzienności i w obrzędach, w których składanie świadectw czy też dzielenie się nimi odgrywa istotną rolę (udaje się oczywiście najlepiej tym z nas, którzy - jak np. Noemi Modnicka - są i „tubylcami”, i „badaczami”) (Modnicka 2010).

Gdy badacz przybywa do „tubylców” na chwilę, wyposażony w uprzednią wiedzę, że ich wspólnota jest „wspólnotą świadectwa”, każdą wypowiedź - jak we wspólnocie religijnej - pobrzmiewającą konfesyjnie, gotów uznać za świadectwo. Podobnie dzieje się w sytuacji badawczego wkroczenia do świata tych, o których wie się skądinąd, że - ukrywając swoje doświadczenia i przeżycia lub nie mając moralnie usprawiedliwionej sposobności, by je ujawnić - ciągle „milczą". Każde wypowiedziane przez nich słowo bywa wówczas traktowane jako „głos” przebijający się przez traumę bądź społeczne wykluczenie, a przez to jako świadectwo. Przyjąwszy taką badawczą optykę, zaufać można zawartej w nim autoprezentacji lub - mając własne wyobrażenie o tym, czym jest świadectwo, np. religijne - uznać arbitralnie, że zamiast ,świadectwa nawrócenia religijnego" usłyszało się tylko „piękną historię". Sam siebie wiele razy przestrzegałem przed wrażeniem, jakie przynosi ,pierwsza lektura”. Oznaczało to jednak przyjęcie wobec wypowiedzi „podających się za świadectwa religijne” hermeneutyki nieufności. Druga lektura może wszak podważyć wrażenie pierwszej i skwitować hermeneutyczny wysiłek stwierdzeniem: „to nie jest świadectwo, chociaż wygląda (i chce wyglądać) na świadectwo religijne". Sięgnięcie w głąb siebie uzmysłowiło mi, że przy obstawaniu, zdawałoby się całym sercem, przy hermeneutyce zaufania, chowam tam również sporo niewiary w to, że każda przedstawiająca się jako religijna lub używająca religijnych atrybutów wypowiedź jest świadectwem, i to właśnie religijnym. Co jest źródłem tej podejrzliwości?

Do podważenia wiary w to, że wypowiedź jest zawsze tego rodzaju, za który się podaje, wystarcza już ogólna wiedza o sposobach używania tekstu w rozmaitych dyskursach, choćby - antropolog skwapliwie się dziś na nie otwiera - w dyskursie literackim czy teatralnym. Przypomina Werner G. Jeanrond, iż posługując się „od czasu do czasu [...] pozorami wyznaczników gatunkowych”, pisarze i dramaturdzy „wykorzystują zabieg rodzajowego zwodzenia”: i tak Czekajac na Godota Samuela Becketta, wystawiane jest jako dramat, lecz nie odpowiada on „konwencjonalnym oczekiwaniom”, czyli temu, czego można by się spodziewać po takim gatunku scenicznym. Również inni używali „podobnych zwodniczych technik", by dla czytelnika lub widza jasne się stało, że oczekiwanie tekstu uporządkowanego przez konwencję gatunkową ,nie znajduje pokrycia w dzisiejszym świecie" (J e a n ro nd 1999: 109). Z obserwacji dyskursu publicznego, w tym 
politycznego, płyną takie same sygnały ostrzegawcze. Również - jeśli to sobie tylko uświadomić - z codziennego życia. O jednym ze zwodniczych gatunków tekstu znanym z naszej codzienności J e a n r o n d (1999: 108-109) pisze:

Czasem znajdujemy pod swoimi drzwiami prywatny list. Spodziewamy się, że jest to list od przyjaciela, ale po otwarciu dowiadujemy się, że to jakaś firma wprowadziła nas w błąd, aby na kilka cennych chwil zwrócić na siebie naszą uwagę, na co w innym wypadku nie można byłoby liczyć.

Umyślne „nadużycie gatunków” poświadcza co prawda ich obecność w dyskursie jako form, w które nasza mowa jakby ze swej natury się ,wlewa”, by przywołać Michaiła M. Bachtina, ale też jako norm komunikowania się (poświadcza zaś zgodnie ze znaną prawdą, iż czasem dopiero przekroczenie normy uświadamia jej obecność i jej „niejawnie” dotąd zobowiązującą, ukrytą siłę) - każe zwrócić oczy również na kulturową umowność gatunków:

[...] gatunki są na tyle zgodne z normą, na ile my im to umożliwiamy. Są one rezultatem konwencji komunikacyjnych i przez to same nie posiadają żadnej trwałej mocy. Co więcej, zawsze musimy je dostosowywać do naszych określonych potrzeb komunikacyjnych [...] (Jeanrond 1999: 110).

Argumenty za hermeneutyką podejrzeń płyną także od wyczulonych na podmiany gatunkowe - i obserwujących je w zbieranych przez siebie opowieściach - badaczy narratywistów. Nikogo z nich już chyba nie dziwi stosowanie w opowieściach autobiograficznych podających się za świadectwa religijne szczególnej, łatwo dającej się poznać stylizacji biblijnej. Rzecz w tym, że w niektórych religijnych, chrześcijańskich wspólnotach (może w większości z nich), jest ona przyjmowana nie jako „sztuczny” chwyt retoryczny, ale jako „naturalna” projekcja: rzutowanie losów postaci biblijnych na własne opowiadane życie. Z tekstów biblijnych, zwłaszcza z Ewangelii, bywają też wprost czerpane wzorce opowiadania o chorobie i o cudownym uzdrowieniu, w szczególności schemat narracyjny „choroba - uzdrowienie - dowód”, i w samych Ewangeliach zapewne nieoryginalny (S c hober 1995: kol. 202).

Poważniej rozważają oni natomiast fenomen - tak chciałbym je tu nazywać - gatunków podstawionych. Nie chodzi przy tym o używanie (bo i to się zdarza) nowej formy gatunkowej pod starą nazwą. Próby nazywania wciąż po staremu tego, co już się nie mieści w ramach gatunkowych, ale jeszcze nie ma powszechnie znanej lub wygodnej nazwy (głównie takiej, która by przykuwała uwagę), narażają wprawdzie na zarzut definicyjnej nieadekwatności - rozsadzania nazwy przez jej zakres, lecz nie na zarzut gatunkowego zwodzenia. Nie chodzi również o-właściwe podejściu samego badacza - czytanie opowieści z perspektywy, która nie całkiem odpowiada jej gatunkowości, np. czytanie świadectw religijnych jako baśni, tropienie przeto ich „baśniowości” w przekonaniu, że działają w nich jakieś archetypowe, mityczne - przypominają się tutaj dociekania Northropa 
Frye'a - wzorce narracyjne. Dla tych, co pragną być wierni pierwotnej gatunkowości wypowiedzi, takie czytanie może być czytaniem opacznym, wyczytywaniem z niej bądź wręcz ,wczytywaniem” w nią sensu, którego w niej nie ma (gdy np. z przejęciem śledząc przejawy „wrażliwości mirakularnej” pomyli się religijny sens cudu z „cudownością”). Obrany tutaj „niewłaściwy” sposób analizy i interpretacji mógłby być określony - terminem znanym hermeneutyce biblijnej - jako eisegesis. Sam zastanawiałem się nad tym, czy narzucaniem obcego sensu komunikatywnego nie jest czytanie świadectw choroby jako świadectw religijnych, mimo że one same, chociaż często pobrzmiewają akcentami konfesyjnymi, za świadectwa religijne się nie podają. Słuszną ostrożność wykazały względem takich świadectw Eva Benzein, Astrid Norberg, Britt-Inger Saveman (2001), a Martin E. Marty (b.d.w.) zachował trafny dystans w stosunku do pełnego biblijnych projekcji - sprawozdania z choroby, jakie przedstawił Arthur W. Frank ${ }^{11}$. Nie poprzez wygodne i efektowne, może czasem po prostu nazbyt pospieszne rozpoznania gatunkowe dobijali się więc oni własnego sukcesu hermeneutycznego.

Istotą fenomenu gatunków podstawionych jest to, że zamiast jednego gatunku, w wyniku narracyjnych obejść, stosuje się w dyskursie inną formę gatunkową, np. więc - ta ilustracja zapewnia potrzebną tutaj konkretność - opowieść o własnym życiu z chorobą nie staje się świadectwem choroby, lecz (takie przynajmniej chce czynić wrażenie) świadectwem religijnego nawrócenia. Chwila poważnej zadumy wystarczy, by odgadnąć, że szukanie narracyjnych obejść i podstawianie jednego gatunku za drugi nie dzieje się w „zwykłych” - dla naszej kultury warunkach. Czy zresztą, antycypując sytuacje „niezwykłe”, sama kultura ich nie podpowiada lub nawet nie wymusza? Jakie „niezwykłe” okoliczności wchodzą zatem w grę? Ogólnie biorąc, są to sytuacje obłożenia negatywną sankcją społeczną narracyjnego otwarcia. Temu otwarciu bowiem przeciwstawiają się - rozmaicie kulturowo motywowane - ograniczenia tabuizujące: o chorobie, zwłaszcza własnej i zwłaszcza takiej, która jest uważana za coś niegodnego, wynikającego z grzechu lub krępującego i wstydliwego, nie należy mówić w ogóle albo mówić tylko w wyjątkowych okolicznościach, raczej prywatnych niż publicznych. Nawet w kulturze Zachodu nie każda wspólnota aprobuje, jako formę literacką bądź paraliteracką, autobiografię opartą na wydarzeniu choroby, albo - jeśli je w ogóle zna - przybieranie relacji z własnej choroby lub z choroby kogoś bliskiego (choćby śmiertelnie dotkniętej rakiem matki), w powagę i majestat studium terenowego, ozdobionego szyldem „literatury dokumentu osobistego” albo „autoetnografii”. Uzasadnione na tym tle jest pytanie, czy dla samych autorów nie jest to niekiedy próba znalezienia równowagi, może kompromisu, pomiędzy tym, co zabronione, a tym co dopuszczalne - testowanie granic i delektowanie się chodzeniem po krawędziach. Naruszenie normy uchylić może nawet furtkę

11 Martin E. M a r ty (b.d.w.) postępuje tak w swojej recenzji książki: F r a n k 1991. 
do bohaterstwa: wyznać, że się jest alkoholikiem, ujawnić publicznie (gdy się jest osobą „publiczną”) raka piersi lub prostaty, świadczyć własną opowieścią na rzecz wszystkich cierpiących na stwardnienie rozsiane albo na schizofrenię... Nie wszędzie i nie zawsze posłużenie się autobiograficznym wyznaniem lub autoetnograficznym świadectwem choroby jest jednak możliwe. Gatunki te bywają po prostu kulturowo niedostępne, jak w wypadku chorujących na HIV/AIDS. Zamiast nich pojawić się więc mogą substytuty: do mówienia o takiej właśnie chorobie służyć może - niejako w zastępstwie - forma świadectwa religijnego lub (to zapewne z rozsądnej wstrzemięźliwości i z braku zaufania badacz wybierze takie określenie) pseudoreligijnego.

Dla mnie, patrzącej jak ludzie z Afryki Południowej używają religijnych gatunków konwersji i świadczenia do mówienia o HIV [tłumaczy Corinne S qu i r e (2005: 101), wyróżnienie w oryginale] słuszne wydało się zaproponować, by te gatunki etycznego samootwarcia stały się użytecznymi źródłami narracyjnymi w sytuacji bezpośredniej narracyjnej patologii - jak właśnie w wypadku, gdy tożsamości HIV były postrzegane jako „inne” z powodu swej nieczystości i niemoralności.

Opowiadanie o własnej chorobie, kulturowo oswajane przez użycie gatunków religijnych, sprzyja, jak sądzi Squire, ,uzdrowieniu” narracji społecznej, czyli społecznego dyskursu. Z niemówienia, z milczenia, z narzuconej jej kwarantanny, opowieść wyłania się - bo to przecież „historia zanurzona” - na powierzchnię społecznego życia ${ }^{12}$.

Gdy ktoś teraz mówi, że jego choroba to „dar od Boga”, nie może być ze swoją opowieścią odrzucony poza wspólnotę ani nawet ponownie przez nią ,zatopiony" - zwłaszcza przez wspólnotę, która i z czcią taki dar akceptuje, i z radością gotowa przyjąć, iż stał się on źródłem bądź potwierdzeniem religijnego nawrócenia (i oczyszczenia). Gdy ktoś w ogóle mówi - obrawszy to „obejście” - o tym, że jest nosicielem HIV lub choruje na AIDS, broni „bytowej rangi” własnego życia i choroby przed niwelacją narracyjną. Squire słusznie jednak stawia pytanie, czy gatunek świadectwa religijnego, szczególnie gatunek konwersji, pozwala otworzyć wszystko to, co pozostawało dotąd w „zbawiennym zamknięciu”. Czy pozwala więc wypowiedzieć w pełni - to jej ilustracja - tożsamość kobiety, która w ten sposób jedynie sprawdzała, o ile jest możliwe, by w rodzinie i pośród przyjaciół zaakceptowano jej status nosiciela HIV? Squire twierdzi (a ja jej wtóruję), że nie pozwala wypowiedzieć - czy przed innymi, czy przed samą sobą. To różni te religijne „zastępczo" świadectwa od „prawdziwego” świadectwa nawrócenia, „w którym wiara jest procesem, a nie punktem końcowym”. Jak widać, Squire wątpi, by miały one w pełni religijny charakter, są więc - jak powiada - genre'em kompromisu: niezadowalającego ani od strony choroby, ani od strony wiary religijnej. Od strony wiary religijnej, by podążyć za Squire, kompromis ten może

12 Termin ,historia zanurzona” został przeze mnie użyty i objaśniony w jednej z wcześniejszych prac (We j 1 a n d 2004: 64). 
jednak obiecywać ,„prawdziwe nawrócenie”. Wspólnota akceptująca wartości religijne (a zatem nie po prostu „wspólnota religijna”), chociaż pewna, że ma do czynienia z pseudoświadectwem religijnym, zajmuje wobec niego taką postawę, jak gdyby było ono świadectwem religijnym par excellence - tego zaś nigdy się nie odrzuca, dopuszczając, że to Bóg wybrał je jako drogę autentycznego nawrócenia. W swojej ułomnej postaci, podparte takim wyjaśnieniem, pseudoświadectwo może nawet zostać włączone w obrzęd dzielenia się świadectwami - w nim również świadectwa choroby ,przebrane” za świadectwa religijnego nawrócenia nabierają społecznej mocy. Uderza wszak (dodaję tę myśl do ustaleń Squire), jak ów quasi-religijny genre łatwo zastosować - jak dobrze muszą być w danej kulturze znane wzorce narracji religijnej i z jaką łatwością można z nich korzystać ${ }^{13}$.

\section{ROZPOZNAĆ ŚWIADECTWO: PAUL RICOEUR I KRYTYCZNA LEKTURA ŚWIADECTW}

Wątpliwość dręcząca Ricoeura dotyczyła - co wypada na koniec wyjaśnić - pojęcia rozpoznania. Miał z nim R i c o e u r (2004: 5) ten problem, że słowo to „bez przerwy” pojawiało się w wykładach, jakie przedstawiał pewnemu uczonemu gremium, ,już to prawem kaduka, już to na prawach gościa, w niektórych miejscach wręcz oczekiwanego". Bojąc się jednak albo jego semantycznej pustości czy miałkości, albo też posądzenia (sam mógł się o to oskarżyć), że używa go jako wytrychu zamiast zadbać o to, by pojęciowe klucze były do rozważań dobrze dopasowane, z pojęciem - jednak nie ,pseudopojęciem” - rozpoznania dzielnie się od razu zmierzył: rozpoznał jego całe, hierarchicznie uporządkowane pole znaczeniowe. Na swój sposób i ja próbowałem to zrobić tutaj z pojęciem świadectwa, co prawda bez zamiaru objęcia dociekaniami jakiegoś kompletu powiązanych ze sobą pojęć świadectwa, lecz na pewno z chęcią rozpoznania w nim tego, co miało najściślejszy związek z moim badaniem świadectw charyzmatycznych i co mnie samemu - zaprawionemu w bojach konceptualnych - sprawiało większe lub mniejsze trudności. Nazwałem je ku przestrodze pułapkami, wierząc w to, że jeśli je wskażę, łatwiej będzie innym - nie tylko nie wpaść w nie, ale też, gdy już wpadną, umieć się do tego przyznać. Sam w swoich badaniach odebrałem niezłą lekcję pokory, pisanie o niej to dla mnie może teraz okazja do ekspiacji za badawcze słabości i przewiny, po części także i sposobność świadczenia

13 Opuszczam tutaj - wart jednak uwagi - wątek dobroczynności, czyli korzystnego wpływu narracji na chorych na HIV/AIDS lub w ogóle na (poważnie) chorych, a chcących o swojej chorobie opowiadać, także wątek asymilacji poprzez opowieść, doświadczenia życia z HIV/AIDS. Piszą o tym niezwykle kompetentnie Katarzyna S t e m p l e w s k a-Ż a k o w i c z i Bartosz Z a 1 e w s k i (2010: 17-51). W sprawie stygmatyzującego działania choroby HIV/AIDS w kontekście kulturowym badanym przez Squire ciekawie wypowiadają się inni autorzy (patrz D e a c o n, S t e p h n e y, Prosalendis 2005). 
na podstawie własnego doświadczenia o potrzebie wzmożonej, krytycznej - jak u Ricoeura - metodologicznej autorefleksji.

Co do słowa „rozpoznanie”, które zawsze lubiłem, a pod wpływem Ricoeura polubiłem jeszcze bardziej: u mnie - jak u niego - pojawiało się ono w tych rozważaniach „bez przerwy”. Przyjmowałem je w znaczeniu, które on określa jako podstawowe, „w sensie «identyfikacji-odróżniania»” (R i c o e u r 2004: 14). Identyfikować odróżniając to uznawać, brać za coś, „traktować [przedmiot] jako należący do jakiejś kategorii (gatunku, rodzaju) bądź wchodzący w zakres jakiegoś pojęcia ogólnego" (R i c o e u r 2004: 8) ${ }^{14}$. To podstawowe znaczenie słowa „rozpoznanie” wykorzystałem przede wszystkim przy omawianiu ostatniej z pułapek, odnoszącej się do czytania jako świadectw, zwłaszcza religijnych, wypowiedzi, które za takie się podają. „Czytanie” to właśnie rozpoznanie w lekturze - w pierwszej mogącej zwieść lekturze, lecz również w pogłębiającej ją analizie i interpretacji. Niełatwo temu zwodzeniu się przeciwstawić. Wyjaśniając, czemu w lekturze autofikcje mieszają się z (prawdziwymi) autobiografiami, Philippe L e j e un e (2010: 125) napisał: „Większość autofikcji czyta się jako autobiografie. Czytelnicy nie mogliby postąpić inaczej. Są to bowiem autobiografie, które krętymi ścieżkami zdążają ku prawdzie". W chwilę potem zaś przywołał swojego przyjaciela, Michela Brauda, specjalistę od dzienników, twierdzącego, iż ,[...] zdarzają się autofikcje, które posługują się formą dziennika, lecz [...] nie są one prawdziwymi dziennikami" (L e j e u n e 2010: 131).

Rozpoznać coś jako coś „,prawdziwego”, „autentycznego” i nie dać się zwieść - oszukać czy wprowadzić w błąd - przez to, co tylko prawdziwe i autentyczne udaje, co jest na nie upozowane, wystylizowane, co przybiera jego maskę - to, jak widać, problem ogólniejszy. Niewiele zaryzykuję stawiając tezę, że w świecie kultury współczesnej, kochającej grę pozorów i fikcję, podważającej co krok (czasem efekciarsko, a czasem na poważnie) ,prawdziwą prawdę”, dotyczy on nie tylko - studiowanych przez antropologów kultury i innych badaczy humanistów - opowieści, zwłaszcza autobiografii, dzienników czy relacji chcących być świadectwami.

\section{BIBLIOGRAFIA}

A b e 11 Peter (1975), Modele w socjologii, PWN, Warszawa.

B e n z e in Eva, N or b erg Astrid, S a v e m a n Britt-Inger (2001), The Meaning of the Lived Experience of Hope in Patients with Cancer in Palliative Home Care, „Palliative Medicine”, Vol. 15, s. 117-126.

B e v e r l e y John (2009), Narracja świadka, podrzędność i autorytet narracyjny, [w:] Metody badań jakościowych, t. 1, N. K. Denzin, Y. S. Lincoln (red.), Wydawnictwo Naukowe PWN, Warszawa, s. 761-774.

${ }_{14}$ W tym miejscu Ricoeur przytacza - używając tekstowego wyróżnienia, które ja tu dla prostoty pomijam - fragment hasła ze słownika Le Grand Robert. 
Biblia Tysiaclecia, Pallotinum, Poznań-Warszawa 1984.

B o c h n e r Arthur P. (2001), Narrative's Virtues, „Qualitative Inquiry”, Vol. 7, No. 2, s. 131-157.

Boskie Oko, czyli po co czlowiekowi religia, z o. Joachimem Badenim i o. Janem Andrzejem Kłoczowskim rozmawiaja Artur Sporniak i Jan Strzałka (2003), Wydawnictwo Literackie, Kraków.

B r o o k s Linda Marie (2005), Testimonio's Poetics of Performance, „Comparative Literature Studies", Vol. 42, No. 2, s. 181-222.

C s o r d a s Thomas J. (1994), The Sacred Self: A Cultural Phenomenology of Charismatic Healing, University of California Press, Berkeley-Los Angeles-London.

C z e r m i ń s k a Małgorzata (2000), Autobiograficzny trójkąt. Świadectwo, wyznanie, wyzwanie, Universitas, Kraków.

D e a c o n Harriet, S t e p h n e y Inez, P r o s a 1 e n d is Sandra (2005), Understanding HIV/AIDS Stigma. A Theoretical and Methodological Analysis, HSRC Press, Cape Town.

D ij k Teun A. van (1984), Stories about Minorities, [w:] Teun A. van Dij k, Prejudice in Discourse. An Analysis of Ethnic Prejudice in Cognition and Conversation, John Benjamins Publishing Company, Amsterdam - Philadelphia, s. 79-104.

D i j k Teun A. van (1989), Predubeżdenija $w$ diskursie. Rasskazy ob etniczeskich menszinstwach, [w:] Teun A. van Dij k, Jazyk, poznanie, kommunikacija. Sbornik rabot, Progress, Moskwa, s. $190-227$.

D z i e w u 1 s k i Grzegorz (2002a), Martyrologiczny argument, [w:] Leksykon teologii fundamentalnej, M. Rusecki, K. Kaucha, I. S. Ledwoń, J. Mastej (red.), Wydawnictwo „M”, LublinKraków, s. 774-779.

D z i e w u 1 s k i Grzegorz (2002b), Świadectwo chrześcijańskie, [w:] Leksykon teologii fundamentalnej, M. Rusecki, K. Kaucha, I. S. Ledwoń , J. Mastej (red.), Wydawnictwo „M”, LublinKraków, s. 1189-1191.

E 11 i s Carolyn, B o c h n e r Arthur P. (1999), Bringing Emotion and Personal Narrative into Medical Social Science, „Health”, Vol. 3, No. 2, s. 229-237.

En g e 1 k ing Barbara (2001), Zagłada i pamięć. Doświadczenie Holocaustu i jego konsekwencje opisane na podstawie relacji autobiograficznych, Wydawnictwo IFiS PAN, Warszawa.

E v d o k i m o v Paul (1996), Poznanie Boga w tradycji wschodniej. Patrystyka, liturgia, ikonografia, Wydawnictwo „M”, Kraków.

F r a n k Arthur W. (1991), At the Will of the Body: Reflections on Illness, Houghton Mifflin, Boston.

Gr z e g o r c z y k Andrzej (1983), Próba treściowego opisu świata wartości i jej etyczne konsekwencje, Ossolineum, Wrocław.

H a m m e r s 1 e y Martyn (2006), Sensitizing Concepts, [w:] The Sage Dictionary of Social Research Methods, V. Jupp (ed.), Sage Publications, London-Thousand Oaks (CA), s. 279-280.

H é b r a r d Monique (1994), Charyzmatycy. Zarys historii Odnowy w Duchu Świętym: fakty, postacie, wydarzenia, Wydawnictwo „M”, Kraków.

H e r b e r t Joanna, R o d g e r Richard (2007), Frameworks: Testimony, Representation and Interpretation, [w:] Testimonies of the City. Identity, Community and Change in a Contemporary Urban World, R. Rodger, J. Herbert (eds.), Ashgate Publishing, Hants-Burlington (VT), s. $1-19$.

H o o n a a r d Will C. van den (2008), Sensitizing Concepts, [w:] The Sage Encyclopedia of Qualitative Research Methods, Vol. 2, L. M. Given (ed.), Sage Publications, Thousand Oaks (CA)London, s. 812-814.

J e a n r o n d Werner G. (1999), Hermeneutyka teologiczna, Wydawnictwo WAM, Kraków.

J o h n s t o n Ronnie, M c I v or Arthur (2007), Narratives from the Urban Workplace: Oral Testimonies and the Reconstruction of Men's Work in the Heavy Industries in Glasgow, [w:] Testimonies of the City. Identity, Community and Change in a Contemporary Urban World, R. Rodger, J. Herbert (eds.), Ashgate, Hants-Burlington (VT), s. 23-44. 
K a fa r Marcin Andrzej (2004), Od spotkania do wspólnoty. Autobiograficzny raport z terenu, [w:] Codzienne i niecodzienne. O wspólnotowości w realiach dzisiejszej Łodzi, G. E. Karpińska (red.), ser. „Łódzkie Studia Etnograficzne”, vol. 43, Polskie Towarzystwo Ludoznawcze, Łódź, s. 79-101.

Katechizm Kościoła Katolickiego (1994), Pallotinum, Poznań.

$\mathrm{K}$ a $\mathrm{z}$ Jack (2001), From How to Why. On Luminous Description and Causal Inference in Ethnography (Part I), „Ethnography”, Vol. 2, No. 4, s. 443-473.

K o h l e r Ri e s s m a Catherine (2000), Narrative Analysis, [w:] The Qualitative Researcher's Companion, M. A. Huberman, M. B. Miles (eds.), Sage Publications, London-Thousend Oaks (CA), s. 217-270.

K o hle r Ri e s s man Catherine (2001), Analysis of Personal Narratives, [w:] Handbook of Interview Research, J. F. Gubrium, J. A. Holstein (eds.), Sage Publications, Thousand Oaks (CA)-London, s. 695-710.

K r e i s w i r th Martin (2000), Merely Telling Stories? Narrative and Knowledge in the Human Sciences, „Poetics Today”, Vol. 21, No. 2, s. 293-318.

L a $\mathrm{n}$ g e r Lawrence L. (1991), Holocaust Testimonies, Yale University Press, New Haven (CT).

L a n g e r Wolfgang (1995), Opis przeżycia, [w:] Praktyczny słownik biblijny, A. Grabner-Haider (red.), PAX, Warszawa, kol. 898.

L e j e u n e Philippe (2010), „Drogi zeszycie...”, ,drogi ekranie...”. O dziennikach osobistych, Wydawnictwa Uniwersytetu Warszawskiego, Warszawa.

L i n c o ln Yvonna S. (2000), Narrative Authority vs. Perjured Testimony: Courage, Vulnerability and Truth, „Qualitative Studies in Education”, Vol. 13, No. 2, s. 131-138.

Marty Martin E. [b.d.w.], In the Belly of Illness, [w:] Arthur W. F r a n k, Book Review: „At the Will of the Body: Reflections on Illness", http://www.religion-online.org/showarticle.asp? title=305, 28.09.2011.

M e r t o n Robert K. (1982), Teoria socjologiczna i struktura spoleczna, PWN, Warszawa.

M e r t o n Robert K. (2011), The Ambivalence of Scientists, [w:] The Dynamics of Modern Society, W. J. Goode (ed.), Aldine Transactions, Piscataway (NJ), s. 282-295.

M o d n i ck a Noemi (2010), Misjonarz? Zdrajca? Badacz! O problemach etycznych $w$ badaniu własnej grupy religijnej, [w:] K. K a n i o w s k a, N. M o d n i c k a (red.), Etyczne problemy badań antropologicznych, ser. „Łódzkie Studia Etnograficzne”, vol. 49, Polskie Towarzystwo Ludoznawcze, Wrocław-Lódź, s. 115-137.

N a n c e Kimberly A. (2006), Can Literature Promote Justice? Trauma Narrative and Social Action in Latin American "testimonio", Vanderbilt University Press, Nashville.

N o w a k Małgorzata Danuta (2005), Świadectwo religijne. Gatunek - język - styl, Towarzystwo Naukowe KUL, Lublin.

P a t t o n Michael Q. (2002), Qualitative Research and Evaluation Methods, Sage Publications, Thousand Oaks (CA)-London.

P a w ło w s k i Zdzisław (1998), Teoria opowiadania P. Ricoeura i jej zastosowanie w Instrukcji „O interpretacji Pisma Świętego w Kościele”, „Studia Włocławskie”, vol. 1, s. 129-141.

P o h j a n he i m o Outi (2002), Healing through Praying in Religious Context. Paper Presented at the III Nordic Seminar in Medical Anthropology, Mekrijärvi, s. 1-19, http://medanthro.kaapeli.fi/nordic2002/papers/Documents/1016118817.24/pohjanheimo.pdf, 9.05.2003.

P o 1 k i ng h o r n e Donald E. (2007), Validity Issues in Narrative Research, „Qualitative Inquiry”, Vol. 13, No. 4, s. 471-486.

P o p k i n Jeremy D. (2002), First Person Narrative and the Memory of the Holocaust, „Idea”, Vol. 9, No. 1, s. 16-25.

R i c o e u r Paul (1980), The Hermeneutics of Testimony, http://www.religiononline.org/showchapter.asp?title=1941\&C=1773, 28.09.2011.

R i c o e u r Paul (1993), Życie w poszukiwaniu opowieści, „Logos i Ethos”, nr 2, s. 225-236.

R i c o e u r Paul (2003), O sobie samym jako innym, Wydawnictwo Naukowe PWN, Warszawa. 
R i c o e u r Paul (2004), Drogi rozpoznania, Wydawnictwo „Znak”, Kraków.

R i c o e u r Paul (2008), Czas i opowieść, t. 3, Czas opowiadany, Wydawnictwo Uniwersytetu Jagiellońskiego, Kraków.

R i c o e u r Paul (2011), Hermeneutyka świadectwa, [w:] Paul R i c o e u r, Nazwać Boga, Wydawnictwo WAM, Kraków, s. 15-46.

R i m m o n-K e n a n Shlomith (2002), The Story of „I": Illness and Narrative Identity, „Narrative”, Vol. 10, No. 1, s. 10-11.

$\mathrm{R}$ i m m o n-K e n a n Shlomith (2006), Concepts of Narrative, [w:] The Travelling Concept of Narrative, M. Hyvärinen, A. Korhonen, J. Mykkänen (eds.), „Collegium. Studies across Disciplines in the Humanities and Social Sciences", Vol. 1, (Helsinki Collegium for Advanced Studies, Helsinki), s. 9-27.

R o o s J. P. (1994), True Life Revisited. Autobiography and Refentiality after the "posts", http:// www.valt.helsinki.fi/staff/jproos/truelife.html, 5.06.2005.

R o o s J. P. (2003), Context, Authenticity, Referentiality, Reflexivity: Back to Basics in Autobiography, [w:] Biographical Research in Eastern Europe: Altered Lives and Broken Biographies, R. Humphrey, R. Miller, E. A. Zdravomyslova (eds.), Ashgate Publishing, Hampshire-Burlington (VT), s. 27-37.

R o s n e r Katarzyna (2003), Narracja, tożsamość i czas, Universitas, Kraków.

R u s e c k i Marian (2002), Wiarygodność, [w:] Leksykon teologii fundamentalnej, M. Rusecki, K. Kaucha, I. S. Ledwoń, J. Mastej (red.), Wydawnictwo „M”, Lublin-Kraków, s. 1328-1334.

R z e p k o w s k a Aleksandra (2009), Sybiracy: wspólnota - pamięć - narracja. Studium antropologiczne, ser. „Łódzkie Studia Etnograficzne”, vol. 48, Polskie Towarzystwo Ludoznawcze, Łódź.

S a ri u s z-S k ą p s k a Izabella (1995), Polscy świadkowie Gułagu. Literatura łagrowa 19391989, Universitas, Kraków.

S c h i ffr i n Deborah (2003), We Knew that's It: Retelling the Turning Point of a Narrative, „Discourse Studies", Vol. 5, No. 4, s. 535-561.

S c h o b e r Walter (1995), Cudowne uzdrowienia, [w:] Praktyczny stownik biblijny, A. Grabner-Haider (red.), PAX, Warszawa, kol. 201-202.

S q u i r e Corinne (2005), Reading Narratives, „Group Analysis”, Vol. 38, No. 1, s. 91-107.

S t e m p l e w s k a-Ż a k o w i c z Katarzyna, Z a l e w s k i Bartosz (2010), Czym jest dobra narracja? Struktura narracji z perspektywy badaczy i klinicystów, [w:] Badania narracyjne w psychologii, M. Straś-Romanowska, B. Bartosz, M. Żurko (red.), Eneteia, Warszawa, s. 17-51.

T i s c h n e r Józef (2006), Filozofia dramatu, Wydawnictwo „Znak”, Kraków.

T u r n e r Victor W. (2006), Las symboli: aspekty rytuałów u ludów Ndembu, Nomos, Kraków.

T u rn e r Victor W. (2010), Proces rytualny. Struktura i antystruktura, Państwowy Instytut Wydawniczy, Warszawa.

Vi c k e r s Margaret H. (2003), Chaos Narratives to Reinstate the Voice of a Survivor of Mental Illness: A (partial) Life Story, „Administrative Theory \& Praxis”, Vol. 25, No. 4, s. 513-528.

W e j 1 a n d Andrzej Paweł (1991), Obrazy grup społecznych. Studium metodologiczne, Wydawnictwo IFiS PAN, Warszawa.

We j 1 a nd Andrzej Paweł (2004), Wspólnota świadectwa. Charyzmatyczne opowieści o uzdrowieniu, [w:] Codzienne i niecodzienne. O wspólnotowości $w$ realiach dzisiejszej Łodzi, G. E. Karpińska (red.), ser. „Łódzkie Studia Etnograficzne”, vol. 43, Polskie Towarzystwo Ludoznawcze, Łódź, s. 29-77.

We j 1 a nd Andrzej Paweł (2010a), Dyskurs i tożsamość. Opowieści we wspólnocie naukowej, [w:] Okolice socjologicznej tożsamości. Księga poświęcona pamięci Wojciecha Sitka, I. Taranowicz, Z. Kurcz (red.), Wydawnictwo Uniwersytetu Wrocławskiego, Wrocław, s. 155-182.

We j 1 a n d Andrzej Paweł (2010b), Latem w parku. Epifanie codzienności, [w:] Lato w mieście. Różne oblicza kultury, R. Godula-Węcławowicz (red.), IAiE PAN, Warszawa, s. 145-162. 
W i e r z b i c k a Anna (1983), Genry mowy, [w:] Tekst i zdanie. Zbiór studiów, T. Dobrzyńska, E. Janus (red.), Ossolineum, Wrocław, s. 125-137.

W i 1 k o ń Aleksander (2002), Spójność i struktura tekstu. Wstęp do lingwistyki tekstu, Universitas, Kraków.

Ż u k r o w s k a Aleksandra (2002), Powrót do źródet wiedzy. W sprawie tradycji filozoficznej kognitywistyki, Scholar, Warszawa.

\section{Andrzej Pawet Wejland}

\section{ANTHROPOLOGIST AND THE CONCEPT OF TESTIMONY. ON SOME PITFALLS IN FIELDWORK}

At the core of considerations included in the article, lies a belief that the concept of testimony perhaps because it is today used by anthropologists so willingly and with such contentment - requires a thorough methodological reflection. This very reflection is encouraged not only by semantic vagueness of the word "testimony" and confusing variety of theoretical ways of removing it. I express here the idea that the reflection is primarily forced by difficulties and risks which anthropologists face - especially those narrativistically oriented - during a field research focused on testimonies and communities sharing testimonies. Using my own experiences of studying religious testimonies in groups within the Catholic Charismatic Renewal, I identify four pitfalls that await anthropologists.

The first one, resulting from a narrativistical enchantment, is an excessive willingness to recognize as testimony every single story - heard or read - in particular, on "difficult issues", while testimonies are only those stories - always clearly associated with a characteristic Sitz im Leben which have distinctive features of genre (for testimonies such a natural life setting is a community discourse based on sharing them). The second pitfall is connected with anthropologists' defensive gesture towards some traditionally thinking historians, requesting a confirmation of the "historical truth" of testimonies, that is their compatibility with "objective facts". Nonetheless, focusing attention on the "narrative truth", when exaggerated, makes anthropologists overlook the fact that testimonies always remain in fetters of the "historical truth". Declaration: "I was there at that time" that is, an eye witnessing declaration, must be treated seriously, if they do not wish to deal with pseudo-testimonies. The third pitfall arises due to mixing anthropological naivety with anthropological hubris, and results from an unconfirmed intuition that their own interpretations of testimonies enjoy universal validity. Confronting my own interpretations, considering the notion of a person as it was understood within the charismatic community, with different interpretations by Thomas J. Csordas dampened this easy belief that an anthropologist, using his "double hermeneutic" reveals, present everywhere and permanently in a charismatic community discourse that is, in its own way unique, "native exegesis". The fourth pitfall appears when anthropologist overly trust the use of the word "testimony" by the "natives" that is, too hastily acknowledges that he understands the word just like they do, because, for instance, as a Catholic, he has some "natural" insight into their community discourse. Sometimes it is also about failing to see that within the discourse occurs a substitution of one genre by another, as in the case when a testimony concerning a socially unacceptable illness hides in the guise of a religious testimony.

Methodological reflection, to which I wish to convince anthropologists with this article, as its chief motive accepts - as understood by Paul Ricoeur - hermeneutical impulse for recognizing testimonies conceptually.

Keywords: concept of testimony, religious testimonies, Catholic Charismatic Renewal, hermeneutics of testimony, pitfalls in the anthropological field research. 